\title{
Global Panopticism: States, Corporations, and the Governance Effects of Monitoring Regimes
}

\author{
Larry Catá Backer \\ Tulane Law School
}

Follow this and additional works at: https://www.repository.law.indiana.edu/ijgls

Part of the Civil Law Commons, and the International Law Commons

\section{Recommended Citation}

Backer, Larry Catá (2008) "Global Panopticism: States, Corporations, and the Governance Effects of Monitoring Regimes," Indiana Journal of Global Legal Studies: Vol. 15 : Iss. 1 , Article 6.

Available at: https://www.repository.law.indiana.edu/ijgls/vol15/iss1/6

This Symposium is brought to you for free and open access by the Law School Journals at Digital Repository @ Maurer Law. It has been accepted for inclusion in Indiana Journal of Global Legal Studies by an authorized editor of Digital Repository @ Maurer Law. For more information, please contact rvaughan@indiana.edu.

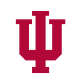

JEROME HALL LAW LIBRARY

INDIANA UNIVERSITY

Maurer School of Law
Blooming ton 


\title{
Global Panopticism: States, Corporations, and the Governance Effects of Monitoring Regimes
}

\author{
Larry Catá Backer*
}

Abstract

Regulatory power has become fractured. Its assertion both by public and private bodies is well known. Less well recognized is that the expression of this regulatory power has been fracturing as well. No longer confined to positive regulation or judicial decision, the techniques for enforcing regulation are substituting for regulation itself. This paper examines surveillance as a mechanism through which power is asserted and regulation effected in a world of shared public/private governance. For this purpose, understanding the nature of surveillance as a technique of governance, and as a substitute for governance itself, is a key element for understanding political authority as it is developing. The paper focuses on surveillance as a new form of lawmaking through which the old boundaries between the public and private, national and transnational, are not relevant. It explores the ways in which the construction of complex systems of conscious and permanent visibility affects the power relationships among states, economic entities and individuals. To understand the complexities and vectors of surveillance is to grasp the shape of converging public/private governance in this century. To that end, this paper first suggests an approach to the unbundling of the normative and methodological assumptions of surveillance. That approach can be usefully divided into four aspects, normative, informatics, control, and governance, each of which is developed in turn. The paper ends with an elaboration of the regulatory consequences of the manipulation of these aspects of surveillance. Drawing on theories of gouvernmentalité, the paper suggests the ways in which governance is increasingly

* Visiting Professor of Law, Tulane Law School; Professor of Law, Pennsylva nia State University; Director, Coalition for Peace \& Ethics, Washington, D.C. I can be contacted at lcb911@gmail .com. An earlier version of this article was presented at the Indiana Journal of Global Legal Studies Symposium on Democracy and the Transnational Private Sector, Indiana University School of Law-Bloomington, April 12,2007. My thanks to the participants for their comments and observations.

Indiana Journal of Global Legal Studies Vol. 15 \#1 (Winter 2008)

CIndiana University School of Law 
elaborated through the techniques of its own power. The attention lavished on surveillance in its many forms evidences the ways in which law, in a sense, is now expressed through different forms.

\section{INTRODUCTION}

This article interrogates one critical aspect of complexity and fracture in regulatory power.' Specifically, it focuses on surveillance ${ }^{2}$ as a regulatory mechanism. ${ }^{3}$ I will explore some of the complexities of this regulatory mechanism in emerging governance systems in which private entities are engaged in sovereign functions and public entities participate in the market. The thesis of this article is fairly straightforward: surveillance represents a complex of assumptions and objectives beyond mere information gathering or observation. Surveillance serves both instrumental and substantive purposes that affect the power relationships among states, economic entities, and individuals. ${ }^{4}$ It is both technique and the reification

1. See, e.g., Claus Offe, Modernity and the State 3-30 (1996). The question of the bases of regulatory power, its complexity and fracture, has long obsessed Western thought. From the active bureaucratism of Weber to the passive self-disciplined panopticism of Foucault the forms of regulatory control have proven to be flexible, subtle and multi-sourced. See Max Weber, The Theory of Social and Economic Organization (A.M. Henderson \& Talcott Parsons trans., Talcott Parsons ed., 1947); Michel Foucault, Governmentality, in The Foucault Effect: Studies in GovernMEnTality 87 (Graham Burchell, Colin Gordon \& Peter Miller eds., 1991). For a valuable analysis, see Michael Reed, From the 'Cage' to the 'Gaze'? The Dynamics of Organizational Control in Late Modernity, in Regulation and Organizations: International Perspectives 17, 43 (Glenn Morgan \& Lars Engwall eds., 1999) (exploring the thesis that "bureaucratic control is giving way to a qualitatively different regime of control based on a contrasting trajectory and logic of regulative ordering in which intensive, but remote and dispersed, scanning of organizational behavior and its 'normalizing' effects are the key features.").

2. See, e.g., James R. Beniger, The Control Revolution: Technological and Economic Origins of THE INFormation Society 6-27 (1986) (looking to the late $19^{\text {th }}$ century as the time in which the technologies of control were developed sufficiently to support the development of the modern social order in which governance, management and control increasingly conflated private and public life).

3. Much legal academic discourse has focused on surveillance as it affects privacy rights. In this sense, surveillance is understood solely as technique, technique with an important though incidental effect on the object of legal analysis-"privacy" or "rights." See, e.g., Priscilla M. Regan, Legislating Privacy: Technology, Social Values and Public Policy 1-24 (1995). The further development of this useful discourse is not undertaken in this article.

4. In the context of traditional analysis-the monitoring of individual behavior, "surveillance today sorts people into categories, assigning worth or risk, in ways that have real effects on their life-chances. Deep discrimination occurs, thus making surveillance not merely not a matter of 
of norms that shape the specific character of the gaze. ${ }^{5}$ Surveillance is both ministerial-the gathering of information-and administrative-the elaboration of judgments of the importance of the actions or individuals observed. Surveillance is also a function of its techniques. ${ }^{6}$ The technologies of surveillance suggest the limits of the gaze and the scope of control through visibility. While virtually everything can be monitored, power (and the limits of power) is a function of control over the way power is understood, gathered, and used. Moreover, the power to decide what parts of monitored activity may be revealed, extracted, analyzed, judged, and relied on has important consequences, consequences that themselves are the subject of further surveillance.

Surveillance is one of the critical mechanisms of this expansion of private power into what had been an exclusively public sphere. Increasingly, public bodies are requiring, or permitting, private entities to monitor and report on the conduct and activities of a host of actors. It increasingly serves public bodies as a substitute for lawmaking. Surveillance is a flexible engine. It can be used to decide what sorts of facts constitute information, to determine what sorts of information ought to be privileged and which do not matter, to gather that information, to empower people or entities to gather information, and to act on the information gathered. In its domestic form it can be used to assign authority over certain types of information to private enterprises and then hold those enterprises to account on the basis of the information gathered. ${ }^{8}$ In its transnational form it can be used to construct a set of privileged information that can be gathered and distributed voluntarily by private entities on the basis of systems created and maintained by

personal privacy but of social justice." David Lyon, Introduction to Surveillance as Social Sorting: Privacy, Risk and Digital. Discrimination 1-9 (David Lyon ed., 2002).

5. It affects not only the relationship among institutions, public and private, that is the subject of this article, but the power dynamics of individual relationships as well. See Jefrrey Rosen, The Unwanted Gaze: The Destruction of Privacy in America 90-127 (2000) (describing the conflation of public and private in the context of a sexual harassment suit involving the magazine SPIN).

6. See Michel Foucault, Security, Territory, and Population, in Michel Foucault, Ethics: SubJectivity and Truth 67-71 (Paul Rabinow ed., 1997); see also infra Part IV.

7. See, for example, the essays in Technology and Privacy: The New Landscape (Philip E. Agre \& Marc Rotenberg eds., 1998) (exploring the current state of technology based privacy issues). "At the beginning of the twenty-first century, new technologies of communication have increased the danger that intimate personal information originally disclosed to friends and colleagues may be exposed to-and misinterpreted by-a less understanding audience." Rosen, supra note 5, at 7. The relationship between technology and surveillance, between technique and object, informs a large part of this essay.

8. Sarbanes-Oxley Act of 2002, Pub. L. No. 107-204, 116 Stat. 745, codified at various places in 15 U.S.C. 
international public or private organizations as an alternative to formal regulation and to provide a means of harmonizing behavior without law. ${ }^{9}$ Surveillance in its various forms provides a unifying technique with which governance can be effectuated across the boundaries of power fractures without challenging formal regulatory power or its limits. It avoids the barrier between the public and private spheres; it substantially increases the regulatory palette of states without the complications of the usual limitations of public formal lawmaking-especially those of accountability and transparency.

The consequences of surveillance, particularly those consequences on the shape of governance, are to a great extent a function of the character of the surveillance power elaborated. ${ }^{10}$ The principal effects will tend to promote a further convergence of public and private regulatory power." This convergence arises from a fracturing of traditional divisions of power. ${ }^{12}$ A sovereign is said to lose its character as such when it "acts, not as regulator of a market, but in the manner of

9. See The United Nations Global Compact, What is the Global Compact, http://www.unglobal compact.org/AboutTheGC/index.html.

10. The range of public and private surveillance even on individuals provides a descriptor of the range of surveillance as technique and its object as regulator of behavior:

You are under surveillance. Not many years ago, this statement could not have been made in a generalized form to an unknown addressee. Today, assuming that you are an urban dweller in a developed country, to be 'under surveillance' is a general condition. Cameras watch over you as you journey to work, registering your number plates or recording your behaviour on the underground train platform. Your image is recorded by every ATM you use, in almost every convenience store you enter, and many times on virtually every street you walk along. Vast commercial data banks assess your shopping habits and your credit history. Intergovernmental networks analyse your phone conversations, searching for key words as indicators of subversion. Your boss is probably recording you too. Your neighbours can now buy satellite pictures of your back yard. In New York, even the police dogs carry cameras. 'You are under surveillance' is no longer an announcement made to a selected individual-it is a description of our culture.

John E. McGrath, Loving Big Brother: Performance, Privacy, and Surveillance Space 19 (2004)(footnotes omitted).

11. There is a substratum of classical totalitarian theory about this rush toward surveillance. Totalitarianism can be understood as grounded in a basic conflation of the individual and her network of social relations in "a substantive identity between collective and individual interests." A. James Gregor, The Ideology of Fascism: The Rationale of Totalitarianism 339 (1969) ("Apart from social relations there is strictly speaking no individuality, no personality, no humanity."). The irony, of course, is that the most successful application of the totalitarian aspects of surveillance culture might well be the states whose self-identification is grounded in a rejection of the totalitarianism, the techniques of which it has been increasingly deploying.

12. But, as Ralf Michaels and Nils Jansen caution us, this area is conceptually fraught with uncertainty. Even the basic understanding of core terms has a certain fluidity that complicates discussion. See Ralf Michaels \& Nils Jansen, Private Law Beyond the State? Europeanization, Globalization, Privatization, 54 Ам. J. Coмp. L. 843 (2006). 
a private player within it."13 The reciprocal principle has not been accepted de jure; a private actor is not said to lose its character as a private actor when it acts in the manner of a sovereign. Still, private players now are required to play the role of regulator and have sought that role for themselves de facto. ${ }^{14}$ And, increasingly, public bodies are requiring, or permitting, private entities to monitor and report on the conduct and activities of a host of actors. ${ }^{15}$

Surveillance, then, functions as more than a descriptor of methodology. Surveillance is a new form of lawmaking through which the old boundaries between the public and private, national and transnational, are made irrelevant. The construction of complex systems of conscious and permanent visibility, as both normative systems and bundles of specific techniques, affects the power relationships among states, economic entities, and individuals. It represents modalities of fractures and complications in assertions of regulatory power, replicating its forms and effects throughout society. ${ }^{16}$ Its privatization tends to complicate the distinction between private and public institutions and between assertions of private (market or personal welfare maximizing) and public (regulatory or stakeholder welfare maximization). Surveillance cuts across borders - it embodies the techniques and sensibilities of an essentially transnational response to problems of governance. ${ }^{7}$ To understand the complexities and vectors of surveillance is to grasp the shape of converging public/private governance in this century.

13. Argentina v. Weltover, 504 U.S. 607, 614 (1992).

14. See OFFE, supra note 1, at 11-12 ("The idea that order can be achieved via the separation of the spheres of economy and politics ... is today in both normative, and ... in descriptive terms, to be banished to the realm of utopian or ideological delusion."). Still, this conflation, and the resulting sharing and movement of power between public and private institutions, troubles some. The trouble is not the use of technology to ramp up the use of surveillance for assertions of public power against individuals, it is the sharing of those techniques and its use by private powers for their own benefit. See Amitai Etzioni, The Limits of Privacy 1-15 (2000).

15. See Dara O'Rourke, Outsourcing Regulation: Analyzing Nongovernmental Systems of Labor Standards and Monitoring, 31 PoL'y STud. J. 1, 23 (2003) ("New nongovernmental regulatory systems ... offer the potential of opening up and strengthening regulatory systems and bringing in new voices and mechanisms for motivating improvements in global supply chains. They also harbor the peril of privatizing regulation, effectively closing off democratic forms of regulation and bypassing local governance.").

16. For a feminist reading of this sort of replication at a basic level of individual-organizational interaction, see Jennifer Robinson, Power as Friendship: Spaciality, Feminity and "Noisy" Surveillance, in Entanglements of Power: Geographies of Domination / Resistance 67-92 (Ronan Paddison et al. eds., 2000).

17. Surveillance is thus affected by the issue of borders and by the means for their overcoming. This is the essence of the problem of transnational law. See Larry Catá Backer, Transnational LAw (forthcoming 2008). 
To that end, this article first suggests an approach to the unbundling of the normative and methodological assumptions of surveillance. That approach can be usefully divided into four aspects: (1) normative, (2) informatics, (3) control, and (4) governance. Each of these aspects of surveillance is then developed in turn. The focus is on the development of an understanding of the mechanical, symbolic, and regulatory functions of surveillance in a context in which these functions tend to leak power between private and public regulatory institutions. This article concludes with an elaboration of the regulatory consequences of the manipulation of these aspects of surveillance. These manipulations are felt as gouvernmentalité, a linking of governance with the techniques of its power. ${ }^{18}$ It serves as a bridge between surveillance as technique and the systemic replication of private desire in collective action. Surveillance has morphed from an incident of governance to the basis of governance itself.

\section{Unbundling Surveillance}

It is not unusual, when people examine issues of governance-whether public or private-to approach the analysis in a way that embraces the value judgments inherent in the normative assumptions and parallels the foundational model of governance of the political community to which they belong. Academics, especially, practice this mode of seeing the world, often to a fault. ${ }^{19}$

In the West, that usually translates into a fixation, of sorts, on the executive, legislative, or judicial function. Division of government along these functional lines is old within Western political tradition. It underlies the construction of the apparatus of governance in the United States and most states in Europe. It has become a basic form of governmental organization on a global scale. Even transnational organizations are conceived, and the value of their institutional forms is debated, on the basis of these functional categories. ${ }^{20}$

Analysis within those functional categories is usually elaborated within a

18. Foucault, supra note 6 , at $67-71$.

19. See, e.g., Larry Catá Backer, The Rule of Law, The Chinese Communist Party, and Ideological Campaigns: Sange Daibiao (the "Three Represents"), Socialist Rule of Law, and Modern Chinese Constitutionalism, 16 J. of Transnat'l L. \& Contemp. Probs. 29 (2006) (discussing the difficulties of applying Western rule of law notions when the object is an understanding of Chinese constitutionalism).

20. See Welber Barral, Dispute Settlement and Legal Harmonization in Mercosur, in Harmonizing Law in an Era of Globalization: Convergence, Divergence and Resistance (Larry Catá Backer ed., 2007); Thomas Andrew O'Keefe, Dispute Resolution in Mercosur, available at http:// www.mercosurconsulting.net/Articles/articlel0.html (last visited Feb. 14, 2008). 
normative framework that is bounded by efficiency concerns and fear of tyranny. ${ }^{21}$ Efficiency concerns are usually expressed in terms of separation of powers analysis. ${ }^{22}$ Fear of tyranny is usually expressed using the imagery of "checks and balances." Americans have been increasingly interested in separation of powers jurisprudence. The jurisprudence of assertions of functionally differentiated power $^{23}$ is an important aspect of American governance in the last half of the twentieth century. And it has tended to inform attitudes toward a mechanics of that expression of power in surveillance. ${ }^{24}$

Checks and balances, on the other hand, at first blush suggest an inefficiency of sorts. It erects blocks on the efficient use of functionally differentiated power. Thus, the executive may not enter into treaties without the advice and consent of the Senate..$^{25}$ Nor can the legislature pass an act without the approval of the executive or by the consent of an overwhelming majority of its members. ${ }^{26}$ Yet, checks and balances also speak to efficiency concerns; not to the efficient deployment of partial governance power (executive, legislative, or judicial), but to the efficient deployment of legitimate governance. ${ }^{27}$ Checks and balances are sometimes thought to be viewed as less compelling than the efficient expression of particularized and functionally differentiated power in the executive, legislative, or judicial organs. The tensions among separation of powers and checks and balances-that is, between efficiency concerns in governance and fear of tyranny in the assertions

21. These ideas are basic to American constitutional case law. See, e.g., Marbury v. Madison, 5 U.S. (1 Cranch) 137 (1803); McColloch v. Maryland, 17 US (4 Wheat) 316 (1819).

22. The debate over the implementation of a "unitary executive" theory in American constitutional law provides an excellent example. See, e.g., Steven G. Calabresi \& Kevin H. Rhodes, The Structural Constitution: Unitary Executive, Plural Judiciary, 105 HARv. L. Rev. 1153, 1165 (1992).

23. On functional differentiation in this context, see Gunther Teubner, Societal Constitutionalism: Alternatives to State-Centered Constitutional Theory, in Transnational Governance and Constitutionalism 3, 13-15 (Christian Joerges et al. eds., 2004).

24. See, e.g., Bob Barr, Post 9/11 Electronic Surveillance Severely Undermining Freedom, $41 \mathrm{VAL}$. U.L. Rev. 1383 (2007).

25. See U.S. Const. art. II, $\S 2$.

26. See U.S. Const. art. I, $\S 7$.

27. Checks and balances thus can be characterized as a certification of legitimacy in accordance with the foundational governance norms of the system-democratic, participatory, and rule bound. See, e.g., Peter M. Shane, When Inter-Branch Norms Break Down: Of Arms-For-Hostages, “Orderly Shutdowns," Presidential Impeachments, And Judicial "Coups," 12 Cornell J.L. \& Puв. PoL'y 503, 505-14 (2003). For its relevance to supra-national governance, see, for example, Fritz W. Scharpf, Problem-Solving Effectiveness and Democratic Accountability in the EU 3-4 (Max Planck Inst. for the Study of Societies, Working Paper No. 03/1, 2003), available at http://www.mpifg-koeln.mpg.de/pu/workpap/wp03-1/wp03-1.html. 
of governmental power-have spilled over into debates about the construction of supranational organizations..$^{28}$

Thus bounded, the system is expressed in both formal systems and positive law making. These formal systems are constituted as an autonomous apparatus, institutions vested with the authority to exercise power on behalf of stakeholders who constitute the governance community, yet separate from these stakeholders. ${ }^{29}$ Positive law making is generalized under the rubric - "rule of law." ${ }^{30}$ It serves as the mechanics of expressions of autonomous institutional power deployed on behalf of the governed by institutions with power over, but autonomous and distinct from, the governed. ${ }^{31}$ Governance is consequently limited to the juridico-legal mechanics through which it finds expression in acts of the sovereign or its corporatist delegee. ${ }^{32}$ It becomes its means of expression (law) and its physical manifestation (government), as a juridical technique through which all else is subsumed. ${ }^{33}$ This provides the conceptual filter through which everything else is understood.

Taken together, then, governance is filtered through an ideological lens that understands power as residing in a functionally differentiated and autonomous institutional system that is expressed in positive law and optimally operational

28. Thus, for example, the applicability of both concepts has informed discussions about reforming the organization of the United Nations. See, e.g., C.L. Lim, The Great Power Balance, the United Nations and What the Framers Intended: In Partial Response to Hans Köchler, 6 CHINEse J. INT'L L. 307, 319 (2007) ("Yet we cannot have it both ways. There is a tension between efficiency and having checks and balances. We cannot say the Council cannot act, and at the same time say there are no checks. The question has not to do with the absence of either but in the tension between them where these two aims must both be fulfilled, in the scheme of the Framers, in ensuring the proper functioning of the Council.").

29. The constitution of "government" has been at the center of the problem of assertion of a regularized and institutional power not only in traditional political communities, in which such constitutions were formalized in a written instrument, but also in Marxist Leninist states, economic communities and supra-national communities. See Backer, supra note 20; Larry Catá Backer, The Euro and the European Demos: A Reconstitution, 21 Y.B. Eur. L. 13 (2002); Larry Catá Backer, Multinational Corporations, Transnational Law: The United Nation's Norms on the Responsibilities of Transnational Corporations as a Harbinger of Corporate Social Responsibility as International Law, 37 Colum. Hum. Rrs. L. Rev, 287 (2006) [hereinafter Multinational Corporations].

30. For a discussion of "rule of law" within the normative boundaries of American jurisprudence from two different and critical perspectives, see Brian Tamanaha, Law as a Menns to an End: Threat to the Rule of Law (2005) and Steven D. Smith, Law's Quandary 5-21 (2005).

31. See Larry Catá Backer, Reifying Law, 26 PeNN St. INT'L L. Rev. (forthcoming 2008).

32. Thus, the formal discourse of law is invoked to mask political struggle over the technologies of control. See Michel Foucault, The History Of Sexuality: An Introduction 145 (Robert Hurley trans., Vintage Books 1990) (1976).

33. See id. at $87-89$. 
when it operates efficiently. This approach is understood as quite reasonable and necessary. It forms the essence of the expression and construction of the regulatory power of states (as sovereign political entities) and corporations (as sovereign economic entities). It also suggests the quality of the relationship between entity, whether public or private, and their respective stakeholders. In the case of public entities, the core stakeholders are citizens and residents. In the case of private entities, stakeholders are security holders. In both cases, of course, there is a substantial debate about the extent of stakeholders entitled to participation. ${ }^{34}$

But, other regulatory functions-for a long time lurking in the background as incidental or secondary-have surged forward from humble beginnings in revolutionary France and then Russia, to move more center stage from the late twentieth century. In a sense, this movement evidences the transformation of those aspects of governance, i.e., the ways in which governance is actually implemented to assume its form that is the substance of regulation itself. ${ }^{35}$ The techniques of governance have moved from secondary to primary organizing forces within governance organizations. "That is, technological artifacts have politics. ${ }^{36}$ They also have regulatory effect. The traditional forms of governance (through law) now serve to hide the realities of technique as governance. This technique is supported by its own governance ideology distinct from that of traditional governance. 37 "Shielded by the conviction that technology is neutral and tool-like, a whole new order is built-piecemeal, step by step, with the parts and pieces linked together in novel ways-without the slightest public awareness or opportunity to dispute the character of the changes underway. ${ }^{\text {"38 }}$

Among the more important of the governance functions - affecting both public and private governance systems-is that of surveillance. ${ }^{39}$ By surveillance I mean to

34. In the case of public entities, for example, the question of the role of undocumented workers has grown in importance. In the case of private companies, the role of non-shareholder stakeholders has become central to the issue of corporate governance.

35. Drawing on the work of Landon Winner, Virginia Eubanks reminds us that the means or "technics" of governance are not limited to those devices through which governance is physically effectuated. But it also includes "the activities-skills, methods, procedures and routines, or techniques-and varieties of social organizations: factories, workshops, bureaucracies, armies and research and development teams." Virginia Eubanks, Technologies of Citizenship: Surveillance and Political Learning in the Welfare System, in Surveillance and Security: Technological Politics and Power in Everyday Life 89, 100 (Torin Monahan ed., 2006) (drawing from Langdon Winner, Autonomous Technology: Technics-of-Control as a Theme in Political Thought 12 (1977)).

36. $I$. .

37. "Technology in a true sense is legislation." WINNER, supra note 35 , at 323.

38. Id. at 324 .

39. The sort of surveillance that is the object of this article is not a specific technique of observation or monitoring, but rather the aggregation of the techniques through which the actions of people and 
invoke the French overtones of the term, to suggest that surveillance is a function of "watching over." But watching over can be understood both as technique (how one watches, what one watches), and as a normative system of watching (the assumptions and justifications for watching and its production of a system of watching). Surveillance, when understood as transparency, has two aspects: internal (direct stakeholders involved in governance) and external (all communities that might be affected). In the former sense, it can be understood as the classical forms of monitoring that have served as the foundation of legal constructs like the duty of care in American corporate law. ${ }^{40}$ In the latter sense, it ranges from the observation of human activity for the protection of the state, to the observation of human activity for economic exploitation. ${ }^{41}$

Surveillance can be said to embrace two principles. First, it embraces a passive (openness) principle. It serves as a record keeper. Surveillance is an aggregate of techniques for the preservation of the current as it moves into the past. It serves as a means, made possible by increasingly effective technologies of recording and preservation, to allow the replaying of the past in the future. This principle embraces the idea of potentiality - the institutional gaze. ${ }^{42}$ It is useful for recreation of events that, projected into the future, indicate action that might be subject to discipline. It extends the time and space for the determination of that disciplining function. ${ }^{43}$ The past, now routinely projected into the present, remains available through recreation, to extract consequences in the future. Yet, it does little more than look-and record-rather than invoke a mechanics of physical coercion. ${ }^{44}$

institutions are made transparent and observable, and on that basis subject to construction or reconstruction on the basis of the data collected applied against the normative framework from which the desire to observe arises. See, e.g., David Lyon, Surveillance Society: Monitoring Everyday Life 28-35 (2001) (surveillance and the techniques of social category sorting in governance); REG WHITAker, The End of Privacy: How Total Surveillance is Becoming a Reality 80-118 (1999) (surveillance as a method of social control); Gary T. Marx, The Surveillance Society: The Threat of 1984-Style Techniques, The Futurist, June 1985, at 21 (on the new techniques of surveillance).

40. See In re Caremark Litigation, 698 A.2d 959 (Del. Ch. 1996).

41. The techniques of surveillance as transparency, that is in its aspect of making the actions of the objects of surveillance transparent, has become increasingly automated and commodified. For a description of the differences between traditional surveillance and the new disciplinary techniques of surveillance, see Gary T. Marx, Surveillance and Society, in Encyclopedia of Social Theory (2005).

42. Foucault famously explained that this gaze "is a machine in which everyone is caught, those who exercise power as much as those over whom it is exercised." Michel Foucault, The Eye of Power, in Power/Knowledge: Selected Interviews and Other Writings 1972-1977 156 (Colin Gordon ed., 1980).

43. See Robert Craig, Panoptic Mediations: From Bentham's Panopticon to the P-Chip, 3 EnculTURATION (Fall 2001), available at http://enculturation.gmu.edu/3_2/craig/index.html.

44. "In contrast to that you have the system of surveillance, which on the contrary involves very little expense. There is no need for arms, physical violence, material constraints. Just a gaze. ... A 
Second, surveillance includes an active (disclosure, monitoring, and assessment) principle. Surveillance is not merely the gaze. It serves as well as the reification of the borders of assertions of power over what can be seen/recorded/reduced to symbolic significance-le regard.$^{45}$ Surveillance in this active mode describes a power principle that may project power in multiple directions. It shapes physical and symbolic space. ${ }^{46}$ But, to the extent it becomes naturalized, that is, ubiquitous in everyday human or institutional behavior, the objects of surveillance may be the agents through which the active principle of surveillance is realized. ${ }^{47}$

In some or all of these aspects, surveillance is sometimes characterized as essential to democratic governance. It is said to further accountability. ${ }^{48}$ It reduces corruption/disloyalty. ${ }^{49}$ And it serves to promote solidarity among stakeholders, promoting management and conflict resolution. ${ }^{50}$ It can also serve to divide, at least in its traditional forms. ${ }^{51}$ In a global order organized as a simple state cen-

superb formula: power exercised continuously and for what turns out to be minimal cost." FouCAuLT, supra note 32 , at 146-65.

45. This suggests an active relationship between subject and object of surveillance. That relationship was nicely fleshed out in the sense I use it here, by Lacan. See Dino Felluga, Modules on Lacan: On the Gaze, in INTroductory Guide to CRitical Theory, available at http://www.purdue .edu/guidetotheory/psychoanalysis/lacangaze.html. But the gaze has an institutional component as well. In that form, it suggests a slightly different form of internalization by the object of surveillance and by its subject. See Foucault, supra note 32, at 146-65 ("An inspecting gaze, a gaze which each individual under its weight will end by interiorisation to the point that he is his own overseer, each individual thus exercising this surveillance over, and against, himself.").

46. See Hille Koskela, "The Gaze Without Eyes:" Video-Surveillance and the Changing Nature of Urban Space, 24 Progress in Human Geography 243, 243-65 (2000) (arguing that "video-surveillance changes the ways in which power is exercised, modifies emotional experiences in urban space and affects the ways in which 'reality' is conceptualized and understood. Surveillance contributes to the production of urban space.").

47. See, e.g., John Edward Campbell \& Matt Carlson, Panopticon.com: Online Surveillance and the Commodification of Privacy, 46(4) J. of Broadcasting \& Electronic Media 586 (2002).

48. See, e.g., Sarbanes-Oxley Act of 2002, supra note 8; Paula Schaefer, Overcoming Noneconomic Barriers to Loyal Disclosure, 44 A м. Bus. L.J. 417 (2007) (analysis of mechanics of promoting seamless and active disclosure).

49. See, e.g., The U.S.A. Patriot Improvement and Reauthorization Act, Pub.L. No. 109-177, 120 Stat. 192 (2005). The United States Department of Justice has developed an extensive web site, the object of which is to support the objectives and legitimacy of this statute. See Department of Justice, Preserving Life and Liberty, http://www.lifeandliberty.gov/index.html (last visited Feb. 28, 2008).

50. See Larry Catá Backer, Monitor and Manage: MiFID and Power in the Regulation of EU Financial Markets, 27 Y.B. Eur. L. (forthcoming 2008).

51. See, e.g., Alan F. Westin, Intrusions: Privacy Tradeoffs In A Free Society, 11 Public PerspecTIVE 8, 8-11 (2000). Westin explains that "In the politics of privacy, the battle is for the hearts and minds of the Privacy Pragmatists. If most of them feel their personal information is being used fairly and properly by businesses, especially online, they join the Privacy Unconcerned to make up 
tered system, territorially bounded and grounded in purely public lawmaking, this relation between transparency and democratic processes can be essentially correct. But in a global order moving toward a multi-centered, transnational, public-private governance framework, this relationship may become more complex. My purpose, then, is to tease out some of the possible complexities of surveillance within the emerging multi-jurisdictional system of global law, and the emerging relationship between surveillance and democratic governance. I then relate both complexity and relationship to emerging public and private governance systems.

Surveillance in our time is being transformed from a general and undifferentiated technique of governance to the active embodiment of governance itself. Surveillance is both the repository of governance norms and the discipline of those norms within any regulatory system. Surveillance is thus a bundle of assumptions, factors, assessments, and actions incarnated on the bodies of the regulated. Surveillance in its modern form represents another step in the perfection of social panopticism, of the creation of systems of social order that are self-regulating and internalized among those regulated. It represents a shifting of coercive power from the external - the state, the police, and the institution to the internal-the individual and the private. As Michel Foucault famously characterized it in another context:

Hence the major effect of the Panopticon: to induce in the inmate a state of conscious and permanent visibility that assures the automatic functioning of power. So to arrange things that the surveillance is permanent in its effects, even if it is discontinuous in its action; that the perfection of power should tend to render its actual exercise unnecessary; that this architectural apparatus should be a machine for creating and sustaining a power relation independent of the person who exercises it; in short, that the inmates should be caught up in a power situation of which they are themselves the bearers. ${ }^{52}$

Thus understood, surveillance becomes self-regarding, the gaze that looks on itself as its own reality. "As sociotechnical systems, then, surveillance and secu-

a $75 \%$ level of support for the existing rules and practices." Id. at 10 . However, methodology matters. "But if most of the Privacy Pragmatists feel that information practices are intrusive or their information is being misused, they join the Privacy Fundamentalists to make up a majority seeking legislative or regulatory measures, or consumer boycotts." Id.

52. Michel. Foucault, Discipline and Punish: The Birth of the Prison 195-228 (Alan Sheridan trans., Vintage Books 2 d ed. 1995) (1977).

53. See, e.g., Slavo Zizek, The Sublime Object of Ideology (1989). 
rity are intimately intertwined with institutions, ideologies, and a long history of inequality. ... From this standpoint, one can begin to ask the kinds of questions worth asking and answering-questions about power. ${ }^{\text {"5 }} 4$ As normative technique, surveillance provides the framework for its mutability, representing a complex cluster of sub-operations whose application can substantially affect the character of the relationship between governed and governing. Surveillance surpasses its technique. This affects all aspects of governance, from formal political governance-like the regulation of American public corporations ${ }^{55}$ - to social governance systems-like the rankings of American law schools. ${ }^{56}$ The gaze defines and regulates all that it sees. ${ }^{57}$ As a normative framework, surveillance is the expression of the behavior rules of the community for whose benefit it is applied. It is a Logos made manifest among the community of believers..$^{58}$ And there may be as many manifestations of the face of divine order as there are communities in a global system made up of multiple communities.

One way to understand surveillance in its governance role is to unbundle the assumptions, objectives, and actions inherent in the term. One useful framework might be to divide surveillance into four principal components, which together comprise what is commonly understood by the term: (1) normative, (2) informatics, (3) control, and (4) governance. I will discuss each in turn. I will then suggest the ways in which changes in the application or construction of each has both substantive and implementary effect. Furthermore, I will propose ways in which surveillance, now conceived as an aggregate of its components, has regulatory effect. The specific nature of those regulatory effects will also be explored. This article ends with an application of the model in a public and a private context.

54. Torin Monahan, Questioning Surveillance and Security, in SurveIllance and Security: Technological Politics and Power in Everyday Life 1, 10 (Torin Monahan ed., 2006).

55. See Larry Catá Backer, Surveillance and Control: Privatizing and Nationalizing Corporate Monitoring After Sarbanes-Oxley, 2004 Мich. St. L. Rev. 327 (2004).

56. See Wendy Nelson Espel \& Michael Sauder, Rankings and Reactivity: How Public Measures Recreate Social Worlds, 113 Aм. J. of Soc. 1, 35 (2007) ("Reflexivity makes the sharp distinction between the act and object of measurement hard to sustain. Because we continually interpret our social worlds, objects are unstable; they emerge and are reconstructed through measurement.").

57. For an early study of the panoptic element in surveillance, see Oscar Gandy, The Panoptic Sort: A Political Economy of Personal Information 15-52 (1993).

58. See Larry Catá Backer, The Mechanics of Perfection: Philosophy, Theology and the Perfection of American Law, in ON Philosophy in American Law (F.J. Mootz ed., forthcoming 2009) ("Selfconstituted communities are bounded by the 'truth' of their constitution... Political communities, like religious and social communities, are bounded by the 'truth' of their constitution-rationally bounded by rules and understandings within which the infinite is possible."). 


\section{Normative Context: The Foundations of Surveillance}

Surveillance, in its normative context, provides the boundaries within which surveillance is comprehended. Normativity, here, suggests both passive and active elements. Norms act on surveillance in its construction as technique. Surveillance is the application of norms both in the construction of the gaze (how are objects observed/recorded) and in the focus of the observation (what is observed/recorded). It is at this level that modern surveillance and the social order in which it is embedded most intimately interact.

The normative aspect of surveillance, thus, can be understood as the product of two definitional categories: substantive and implementation surveillance normativity. Substantive surveillance normativity suggests overarching behavioral constraints. The sources, character, and limitations of these constraints are wellknown. They comprise the morals and ethics of religious, cultural, ethnic, politi$\mathrm{cal}$, and economic systems. And they are sometimes recognized by and normalized within legal systems at the local, municipal, or international levels. Implementation surveillance normativity suggests the normative assumptions shaping approaches to the act of surveillance itself. The focus in this respect is on the nature, character, and scope of appropriate surveillance, and the relationship of the community to monitoring actually undertaken. The normative aspect of implementation is well understood - in the United States it is permissible to seek information about marriage but normatively unacceptable to acquire that information by posting agents of the state in the bedrooms of married couples.

\section{A. Substantive Surveillance Normativity}

Many behavioral rules and outlooks converge at a high level of generality but tend to diverge in their details. Both German and U.S. political systems value human dignity. But the meanings of human dignity, as a theoretical construct and as applied, vary widely between the United States and Germany. In the German system, human dignity is a concept that forms the foundation of the black letter of the Basic Law. ${ }^{59}$ In the United States, that notion has been teased out of the federal constitution in a more contextual stream of analysis-for example,

59. Grundgesetz für die Bundesrepublik Deutschland [GG][Basic Law] art. 1. 
touching on criminal punishment ${ }^{60}$ or abortion. ${ }^{61}$ As a result, social tolerance of surveillance, in both form and use, will differ from society to society and even vary among ostensibly similar societies. ${ }^{62}$

Surveillance systems that ignore or violate substantive norms lose either legitimacy or authority. Such violations expose the system as alien and unnatural, subjecting the system, its operator, and the agents of surveillance, to discipline in accordance with the rules of the normative community whose behavior codes have been violated. Thus, for example, the series of attempts to construct universal monitoring systems as a response to the United States' "War on Terror" produced strong adverse popular reaction in the U.S. to some of those efforts and resulted in the formal withdrawal of the more controversial programs. ${ }^{63}$ As well, the recent attempt by the United Nations to construct systems of global ordering of multinational regulation based in substantial part on "transparency" and reporting regimes grounded in international human rights norms, was abandoned in the face of substantial opposition from large institutional (state and corporate) actors. $^{64}$ Yet, those very systems of transparency-directed toward investor and public regulatory communities and their interests-have become an accepted normative framework for multinational regulation through "voluntary" codes of corporate social responsibility. ${ }^{65}$

While such behavioral frameworks are often universalizing in approach, all

60. Recent $8^{\text {th }}$ Amendment cases have stressed the human dignity component of the analysis. "In Eighth Amendment cases, the Court has repeatedly proclaimed that human dignity underlies the prohibition against cruel and unusual punishment." Maxine D. Goodman, Human Dignity in Supreme Court Constitutional Jurisprudence, 84 NeB. L. Rev. 740, 773 (2006) (citing Trop v. Dulles, 356 U.S. 86, 100 (1958)).

61. See, e.g., Planned Parenthood v. Casey, 505 U.S. 833, 850-51 (1992) ("Personal decisions, such as abortion, are vital to 'personal dignity and autonomy' and thus are protected by the Fourteenth Amendment.").

62. Identity cards, for example, are less tolerated in the United States than in Germany. See Donald Kommers, The Constitutional Jurisprudence of the Federal Republic of Germany (1997).

63. For example, early in the war against Iraq, the Bush administration permitted Admiral Poindexter to suggest a number of vast data gathering efforts, the most notorious of which was the "Total Information Awareness" program. This program, along with a number of others are usefully discussed in Laura K. Donohue, Anglo-American Privacy and Surveillance, 96 J. CR Criminology 1059, 1146 (2006).

64. See Backer, Multinational Corporations, supra note 29, at 287.

65. See, e.g., Org. for Econ. Development \& Cooperation Dev., The OeCD Guidelines for Multinational Enterprises (2002), http://www.oecd.org/dataoecd/56/36/1922428.pdf (recommendations addressed by governments to multinational enterprises in a number of governance areas including employment and industrial relations, human rights, environment, information disclosure, combating bribery, consumer interests, science and technology, competition, and taxation). 
tend to be most important within the communities from which they arise. And all tend to be subject to patterns of interpretive engagement in accordance with the values and rules of the communities in which they are effective. Surveillance substantive normativity, at its most effective, must reflect the overarching behavioral constraints of both the communities within which surveillance arises and within which surveillance is targeted. Where the normative constraints differ, surveillance must be adjusted to fit within the common restraints and beliefs of both. Thus, the greater the number of communities affected by systems of surveillance, the greater the number of likely normative constraints for uniformly applied systems. Alternatively, surveillance must be divided and adjusted to suit the constraints of each. But this raises the costs of surveillance and might increase the variability of information gathered or its utility.

But substantive surveillance normativity also suggests the possibility that surveillance, and especially its technologies, themselves can affect norms. ${ }^{66}$ This is especially the case, for example, with respect to social issues and public perceptions of the realities of social ills. Take, for example, the phenomenon of sexual predators. "Although many people believe that the frequency of sex offending is increasing, there is little convincing evidence that this is, in fact, the case. . . In the 1990s, in an era dominated by technologies of control and risk assessment, many people have called for greater surveillance of these offenders, including electronic monitoring and other such devices." ${ }^{\text {67 }}$ But surveillance systems and the information that it produced may well have facilitated a change in attitudes which in turn made it easier to impose substantially harsher restrictions on the living arrangements of convicted sexual offenders. ${ }^{68}$

More recently explored is the way in which surveillance systems tied to the development of measures to judge the relative quality of U.S. legal education (and

66. This insight is not limited to surveillance. Thus, for example, administrators in Meiji, Japan are said to have understood that "[s]ocial institutions such as technology embody their own worldviews, and once you have adopted a technology, it has an impact on your values. Having accepted the inference that Western technology would bring Western values in its train, some of the more radical Japanese reformers argued for a complete Westernization of Japan in order to save the country." John H. Berthrong, Transformations of the Confucian Way 176 (1998).

67. Mike Hough et al., Penal Populism and Public Opinion: Lessons from Five Countries 129 (2003) ("The latest proposal is to employ the Global Positioning System (GPS) to monitor the location of offenders with convictions for crimes of sexual aggression involving children, and is being used in some jurisdictions in the United States and is being considered in the United Kingdom.").

68. See Caleb Durling, Never Going Home: Does It Make Us Safer? Does It Make Sense? Sex Offenders, Residency Restrictions, and Reforming Risk Management Law, 97 J. CRIM. L. \& CRIMINoLoGY 317 (2006). 
law faculties) have tended to act on those institutions and faculties. ${ }^{69}$ The measures themselves were originally (perhaps) derived from normative assumptions outside the system of monitoring or information harvesting itself. ${ }^{70}$ These quality measures then took on a life of their own." "Rankings have clearly changed how legal educators make decisions about how resources are allocated."

\section{B. Implementation Surveillance Normativity}

If substantive surveillance normativity suggests conformity of technique with the norm systems of the community in which it is deployed, implementation surveillance normativity suggests the normative assumptions shaping approaches to surveillance itself. It embraces not merely behavioral constraints generally understood, but also behavioral assumptions relating to the shape and content of surveillance itself. In addition, surveillance normativity shapes the assumptions about appropriate responses to surveillance by the population monitored as well as by the monitors.

Thus, the focus in this respect is on the nature, character, and scope of appropriate surveillance and the relationship of the community to monitoring. This implicates what in American jurisprudence is known as "privacy," "whistle blow-

69. See generally Espeland \& Sauder, supra note 56, at 1-40.

70. For an interesting discussion in an "as applied" context, see the methodological analysis put forward by Brian Leiter, a legal academic who has made a name for himself as a harvester of facts and manager of knowledge, molded into judgments about both the "rankings" of law schools and the characteristics of law faculty that underlie such judgments. Leiter uses a number of information clusters to elaborate his judgments. See generally Brian Leiter, Brian Leiter's Law School Rankings, http://www.leiterrankings.com/new/index.shtml (last visited Sept. 7, 2007). The search is always for "facts," objective measures. But facts and objective measures invariably descend into the symbolic, or the proxy measure. For example, in the search for a listing of rank based on scholarly impact, Leiter chose as an objective measure citations to work in a particular database owned by Westlaw, an online law source. See Brian Leiter, Top 35 Law Faculties Based on Scholarly Impact (Sept. 1, 2007), available at http://www.leiterrankings.com/faculty/2007faculty_impact.shtml. But citation rates are not a measure of scholarly reputation, the reader is almost immediately informed. It is, instead, its proxy. Id. Although "we might identify six kinds of phenomena at work here which skew the correlation between citation and quality," the result is still useful. Id. The reason is simple: "an imperfect measure may still be an adequate measure, and that is almost certainly true of citation rates as a proxy for impact as a proxy for reputation or quality." Id. Even were this not true at the beginning, as people conform their behavior to the measure, and their understanding of quality to this system, then the measure itself becomes the thing (quality) itself.

71. See, e.g., Michael Sauder \& Ryon Lancaster, Do Rankings Matter? The Effects of U.S. News and World Report Rankings on the Admission Process of Law Schools, 40 L. \& Soc. Rev. 105 (2006).

72. Espeland \& Sauder, supra note 56, at 27. 
ing," and "corruption."73 The focus is also on the extent of an obligation to be open (transparency) or to affirmatively seek information (monitor) as inherent in the assumptions about the relationship of institutions to their stakeholders (from shareholders, employees, directors, and investors to customers and others).$^{74}$

Two movements are worth noting in the construction of the boundaries of surveillance normativity, each of which has significantly altered the framework within which surveillance normativity is understood. The first involves the relationship between surveillance normativity and the organizations/communities/institutions that are the loci of surveillance. That relationship, in the United States, has changed substantially from one based on passivity - that is on the obligation to monitor only after provocation - to one based on an active principle- that surveillance is an essential component of any normative system. Surveillance normativity is grounded in the belief that law is not self-enforcing. Those subject to the obligations of law must be made to obey positive commands, and prevented from shirking their duty to comply with negative obligations (the obligations to refrain from doing). Those subject to such obligations are no longer presumed to do so unless evidence to the contrary is produced. And that compulsion no longer comes at the point of a gun or in the uttering of individual representations of the legitimate authority of the state. Instead, it comes through the gaze; systems of constant observation combined with a self-awareness of being constantly observed that together coerces a particular set of behaviors tied to the character of the observation. Thus, for example, fake Closed Circuit Television (CCTV) cameras around a building may be as effective a deterrent as real CCTV cameras and produce the same behavioral response.

Compliance, then, is a function of both observation and the knowledge of being observed. In some important respects, law is a function of surveillance, that is, the focus of law is on the organization of surveillance, and its application. Law in this sense can be understood as a framework for surveillance, understanding surveillance as information gathering, assessment, and judgment. In the field of corporate regulation in the United States, this foundational normative turn is

73. See, e.g., Terance D. Miethe, Whistleblowing at Work: Tough Choices in Exposing Fraud, Waste, ANd A buse on the Job 36 (1999) ("As a method for detecting and exposing misconduct in the workplace, whistleblowing has no rivals. Alternative methods are simply incapable of achieving the continuous monitoring and insights into organizational practices that are provided by employees themselves. In contrast to other methods of control, whistleblowers provide surveillance and monitoring in all organizations and are better situated in the organizational hierarchy to ask questions to build a solid case against offenders.").

74. Current American securities regulation is grounded in this notion. See JAmes Burk, Values in the Marketplace: The American Stock Market under Federal Securities Law 25-28 (1992). 
nicely exemplified by the move from Graham v. Allis Chalmers ${ }^{75}$ to In re Caremark $^{76}$ as the basis for the legal regulation of surveillance under Delaware corporate law. ${ }^{77}$ In the field of American federal criminal law, it is marked by the progressively more intrusive calculus of federal Attorney General guidelines on prosecution of corporations. $^{78}$ This reflex also has a transnational dimension. The OECD's Anti-

75. Graham v. Allis-Chalmers Mfg. Co., 188 A.2d 125, 130 (Del. 1963) ("Absent cause for suspicion there is no duty upon the directors to install and operate a corporate system of espionage to ferret out wrongdoing which they have no reason to suspect exists.").

76. In re Caremark, 698 A.2d at 970 ("Only a sustained or systematic failure of the board to exercise oversight-such as an utter failure to attempt to assure a reasonable information and reporting system exists - will establish the lack of good faith that is a necessary condition to liability."); In re Walt Disney Co. Deriv. Litig., 906 A.2d 27 (Del. 2006) (affirming and expanding In re Caremark).

77. See Cheryl L. Wade, Racial Discrimination and the Relationship Between the Directorial Duty of Care and Corporate Disclosure, 63 U. Piтt. L. Rev. 389, 403-20 (2002) (arguing that Texaco's corporate response to race-discrimination allegations were in breach of the fiduciary duty of care owed to Texaco's directorate and management). The Delaware Supreme Court has most recently articulated the standard as follows:

We hold that Caremark articulates the necessary conditions predicate for director oversight liability: (a) the directors utterly failed to implement any reporting or information system or controls; or (b) having implemented such a system or controls, consciously failed to monitor or oversee its operations thus disabling themselves from being informed of risks or problems requiring their attention. In either case, imposition of liability requires a showing that the directors knew that they were not discharging their fiduciary obligations. Where directors fail to act in the face of a known duty to act, thereby demonstrating a conscious disregard for their responsibilities, they breach their duty of loyalty by failing to discharge that fiduciary obligation in good faith.

Stone v. Ritter, 911 A.2d 362, 370 (Del. 2006).

78. See Memorandum from Larry D. Thompson, Deputy Attorney General (Jan. 20, 2003), http://www.usdoj.gov/dag/cftf/business_organizations.pdf (The Thompson Memo). The Thompson Memo sets out factors to be evaluated in any Department of Justice determination to prosecute a corporation. Among the most relevant for my purposes here is an evaluation of "compliance programs." The memo explains:

Compliance programs are established by corporate management to prevent and to detect misconduct and to ensure that corporate activities are conducted in accordance with all applicable criminal and civil laws, regulations, and rules. The Department encourages such corporate selfpolicing, including voluntary disclosures to the government of any problems that a corporation discovers on its own. However, the existence of a compliance program is not sufficient, in and of itself, to justify not charging a corporation for criminal conduct undertaken by its officers, directors, employees, or agents. Indeed, the commission of such crimes in the face of a compliance program may suggest that the corporate management is not adequately enforcing its program.

Id. at 8 . The aggressiveness of the government's position in the Thompson Memo has produced a certain negative reaction in the United States federal courts. See, e.g., U.S. v. Stein, 435 F. Supp. 2d 330 (S.D.N.Y. 2006). 
Bribery Convention ${ }^{79}$ is perhaps a case in point. In that context, compliance monitoring serves to discipline conduct and refine the normative context in which monitoring occurs. ${ }^{80}$

The second movement involves the relationship between implementation surveillance normativity and individuals. It is perhaps best understood in the context of the rise of a social "duty of loyalty" for the benefit of the organization rather than for personal benefit) and the consequential focus on "corruption." In the public lending arena this is marked by a move to impose systems of surveillance for government officials. The World Bank's well-publicized programs provide a useful case in point. ${ }^{82}$ Efforts at self-

79. Org. for Econ. Co-operation \& Dev., Convention on Combating Bribery of Foreign Public Officials in International Business Transactions (1998), http://www.oed.org/ dataoecd/4/18/38028044.pdf. Article 12 of the Convention provides:

Article 12 - Monitoring and Follow-up: The Parties shall co-operate in carrying out a programme of systematic follow-up to monitor and promote the full implementation of this Convention. Unless otherwise decided by consensus of the Parties, this shall be done in the framework of the OECD Working Group on Bribery in International Business Transactions and according to its terms of reference, or within the framework and terms of reference of any successor to its functions, and Parties shall bear the costs of the programme in accordance with the rules applicable to that body.

Id. at 8.

80. See, e.g., Org. for Econ. Co-operation \& Dev., The OECD Fights Corruption (2006), http://www.oecd.org/dataoecd/36/51/37418910.pdf. The brochure states:

Countries' enforcement of these measures is systematically monitored to ensure that these instruments are being implemented effectively. This international, mutual evaluation and the peer pressure it has generated over the last decade have stimulated and guided governments to take concrete action to promote integrity in the corporate sector, prevent corruption, and investigate and prosecute cases of foreign bribery.

Id. at 8 . This culture of transparency is reinforced through a series of public mechanisms, including the production of annual reports on compliance that tend to reinforce the norms privileged in the reports. See, e.g., Org. for Econ. Co-operation \& Dev., OECD Working Group on Bribery, AnNUAL RePort 2006 9-14 (2008), http://www.oecd.org/dataoecd/53/29/38865251.pdf.

81. This represents, in effect, a global expansion of the presumptions inherent in the German constitutional notion of Bundestreue. Daniel Halberstam, OfPower and Responsibility: The Political Morality of Federal Systems, 90 VA. L. REv. 731 (2004). In the German constitutional context it suggests a limitation of authority and action-one must act in fidelity to the federal system of which one is a member, "the constitutional duty that the components of the Federation maintain fidelity to one another as well as to the larger whole, that the Federation maintain fidelity to the component parts, and that they all reach mutual understanding." Id., at 757 (citing BVerfGE 1 (1952), 299 (315)). In the context of surveillance norms, it suggests that one must do the same within the institutionalized community in which one is operating-be it company, church, association or state.

82. On the World Bank's anti-corruption programs and its relationship to surveillance, see World Bank, Anti-Corruption Toolkit 6, 214-19 (2001), http://www.worldbank.org/public sector/legal/aclawissues.pdf. 
regulation and structured public/private partnerships thus seek to naturalize a norm set in which surveillance serves as the expression of normative frameworks for behavior in economic enterprises. ${ }^{83}$

The transnational and cultural elements of surveillance are apparent. "At its broadest, information serves in the development and influence on (in totalitarian regimes control of) political, social, economic, and other aspects of culture (that is information gathering has normative consequences well exploited by the state)." ${ }^{\$ 4}$ At the same time, "states have sought to privatize information gathering for its own use in the disciplining of social organization." ${ }^{\text {"s5 }}$ Simultaneously, private institutions seek to reproduce the systems of surveillance either for their own benefit or because they have been compelled to do so for the benefit of a superior institution (usually the state). The distance between public and private becomes more narrow. The characteristics that distinguish the operation of one from the other become less clear. The ability to discern the different fields in which each operates and the different constituencies each serves, becomes harder to identify. What was once relatively unconnected becomes connected through the medium of surveillance. The rule becomes the observable for states as well as for other communities.

\section{Surveillance as Informatics: Building Blocks of Power/Knowledge}

It is in its aspect as the cluster of behaviors we commonly refer to as "informatics" that most people understand surveillance. Surveillance as information suggests a neutral, mechanical, and systems approach to material that already exists. It also suggests a managerial relationship between information and its subject. Surveillance in this sense serves as both the resource and the mechanics of its

83. In the case of World Bank anti-corruption efforts the techniques of surveillance were developed through the Voluntary Disclosure Program (VDP):

which was publicly launched on August 1,2006. Under the VDP, participants commit to: (1) not engage in misconduct in the future; (2) disclose to the Bank the results of an internal investigation into past bad acts in Bank-financed or supported projects or contracts; and (3) implement a robust internal compliance program monitored by a Bank-approved compliance monitor. Participants pay the costs associated with almost every step of the VDP process. In exchange for full cooperation, VDP participants avoid debarment for disclosed past misconduct, their identities are kept confidential, and they may continue to compete for Bank-supported projects.

Margaret Ayres et al., Developments in U.S. and International Efforts to Prevent Corruption, 41 INT'L LAw. 597, 609 (2007) (citations omitted).

84. Backer, supra note 50.

85. Id. 
harvesting. Surveillance, in this aspect, is farming. It accords nicely with the managerialism that has characterized the movement toward bureaucratized governance apparent since the time of Max Weber, in its most sinister aspects. ${ }^{86}$

Informatics involves three distinct sets of actions: data identification (raw information), the practice of data collection (structure and properties of information gathering-knowledge production), and data uses (drawing conclusions from information-judgment function). These three foundational forms of action both define the boundaries of surveillance informatics and suggest its principle variables. These variables consist of (1) data itself (raw information); (2) systems of processing data collections into information useful to someone; (3) systems of evaluating information; and (4) systems of disseminating or communicating information after evaluation. Thus, as informatics, surveillance presents a host of variables grounded in data, on the one hand, and systems, on the other. But surveillance informatics is not concerned with issues either of the identity or character of the recipient of information (issues of to whom is information delivered beyond the person or entity producing the information) or the identity or character of the person or entity that may make use of the information.

\section{A. Data Identification}

Data identification is, on the surface, the easiest marker of surveillance. This is data management at its most raw. It seems simple enough. Data are facts, occurrences, events, or something else that can be recorded, observed, experienced, stored, and retrieved. Yet, data identification is conceptually pregnant with normative and governance significance. The identification itself suggests normative assessment. And the choice of one set of information or data, over others, also suggests normative value. ${ }^{87}$ Consider something straightforward, like the decennial census required under the United States Constitution. ${ }^{88}$ It is possible that the

86. See Max Weber, Economy and Society (1978). See also Martin Schulz, Limits To Bureaucratic Growth: The Density Dependence Of Organizational Rule Births, 43 A pmin. Sci. Q. 845, 845 (1998) ("Bureaucratization is regarded as a rule generation process turned loose. Bureaucracy theorists-as well as much of the general public, including government officials who promise to reinvent government-assume that bureaucracies frantically breed rules, and frequently they imply that rule breeding intensifies as bureaucratization proceeds.").

87. The politics of HIV data collection provides an interesting example, both in its national and transnational aspects. See, e.g., Network Epidemiology: A Handbook for Survey Design and Data Collection (Martina Morris ed., 2004).

88. U.S. Const. art. I, $\$ 2$. 
count must include lawful permanent residents as well as citizens, or perhaps it ought to include all residents, irrespective of their status. The data, themselves, are a function of a political determination. ${ }^{89}$

Data issues center on recognition. The principle variable involves the constitution of data. The foundational issues of data revolve around the questions: What is raw information? What is judgment or conclusion? An easy example of this problem is "race": is it raw data or is it a judgment? ${ }^{90}$ The answer may depend on factors outside of, but informing, the constitution of the data themselves. ${ }^{91}$ The same applies to other data markers-for example, what constitutes corruption ${ }^{29}$ What constitutes sexual deviance ${ }^{93}$ Recognition issues can be manifested in several ways.

89. See, e.g., Daniel Patrick Moynihan, Data and Dogma in Public Policy, 94 J. Am. Stat. Ass'n 359,360 (1999) ("Other areas of data collection unavoidably involve political outcomes such that there are unavoidable political inputs... . Recall that we never did reapportion the House in the 1920 s, following the dread discovery that the nation was no longer predominantly rural. An ingenious member from Kansas proposed that we not count persons not naturalized, and presumably huddled in cities.").

90. See, e.g., Katherine K. Wallman, Data on Race and Ethnicity: Revising the Federal Standard, 52 Am. Statistician 31 (1998).

91. Thus, for example, if it is believed that "race" is constructed, then it doesn't exist as a fact. See, e.g., Ian F. Haney Lopez, The Social Construction of Race: Some Observations on Illusion, Fabrication, and Choice, 29 HARv. C.R.-C.L. L. Rev. 1, 6 (1994). And data on race actually monitor the aggregate assumptions of those who use a variety of (false) classifications to sort people. The data are actually a proxy for the judgment.

92. World Bank, New Empirical Tools for Anti Corruption and Institutional Reform, Helping Countries Build and Implement Effective Anti-Corruption Strategies (2007), http://info.worldbank.org/etools/docs/library/205638/00\%2dintro.pdf; World BanK Institute, Governance: A Participatory, Action-Oriented Program, Program Brief Document 42 (2001), http://www.worldbank.org/wbi/governance/pdf/fy02_brief.pdf (describing among the various programs, a module on "governance data capacity building and monitoring initiative"). The World Bank Institute program:

$[R]$ esponds to the demand for action on governance in developing countries... The assessment will form the basis for a medium- to long-term strategy for building capacity in governance diagnostics and monitoring. The initiative aims to assist developing countries by strengthening their statistical, survey data and analytical capacity, by increasing transparency and access to information using also IT technologies, and by improving the quality of information on governance issues for both Government and civil society generally.

World Bank Institute, Governance: A Participatory, Action-Oriented Program, Program Brief Document 42 (2001), http://www.worldbank.org/wbi/governance/pdf/fy02_brief.pdf.

93. There is a mountain of literature on this subject, sensitive to both the medical and political ramifications of definition, surveillance, and management. See, e.g., Dana Seitler, Queer Physiognomies; or, How Many Ways Can We Do the History of Sexuality?, 46 CR I ICISM 71, 74 (2004) (discussing "pathologizing medical discourses of surveillance and punishment of what would come to be known as 'homosexuality' in the twentieth century."). 
First, related to the problem of the constitution of data (as fact or judgment) is the problem of shifting understanding of the characteristics of facts constituting the data. Science provides a useful example. In collecting data on planets-are data on Pluto to be collected? The answer used to be yes; the current answer is a qualified no. ${ }^{94}$ The celestial body has not changed characteristics, but its quality as data has changed.

Another problem is data source. Where the data source has an interest in the construction and production of data, the data themselves might be corrupted. An example is data collected on factors indicating the success of the Cuban Revolution by the Cuban revolutionary government. ${ }^{95}$ The constitution of data thus is directly influenced by the normative framework within which data are themselves constructed. Even the most basic data can be contested to some extent or reflect the contextual basis in which they are "seen" or understood to constitute "raw data."

\section{B. Data Collection}

The construction of systems for data collection, like data identification, is more complicated than the simple implementation of methods of collection. Structuring information gathering, and the properties of that structuring, implicates the production of knowledge. But the production of knowledge is itself embedded within the cultural matrix in which it operates, even as it contributes to the production and maintenance of that matrix. ${ }^{96}$ Surveillance works to provide the "data" serving as a basis of socially constructed belief, and on that basis on the confirmation of the belief, which is a function of the construction itself. ${ }^{97}$

Collection issues problematize "data" and their identification as such. These

94. See Mason Inman, Pluto Not a Planet, Astronomers Rule, Nat'l Geographic News (Aug. 24, 2006) available at http://news.nationalgeographic.com/news/2006/08/060824-pluto-planet.html.

95. See, e.g., Berta Esperanza Hernandez Truyol, Out in Left Field: Cuba's Post Cold War Strikeout, 18 Fordham INr'L L.J. 15, 18 (1994) (“To maintain the author's commitment to fair, evenhanded analysis and lack of predispositions in evaluating the present situation in Cuba, reliance is placed whenever possible on what can be deemed 'neutral,' i.e., non-ideologically-based data that is gathered by and available from the United Nations.").

96. The sociology of the production of institutionalized legal knowledge is usefully explored in Bourdieu. See Pierre Bourdieu, The Force of Law: Toward a Sociology of the Juridical Field, 38 Hastings L.J. 805 (Richard Terdiman trans., 1987).

97. See Richard Terdiman, Translator's Introduction to Pierre Bourdieu, The Force of Law: Toward a Sociology of the Juridicial Field (Richard Terdiman trans.), 38 Hastings L.J. 805, 806 (1987) (on an explanation of Bourdieu's terminology). 
issues implicate the production of knowledge from data collected. Here the principal focus is on capacity and parameter issues. These include:

(1) Scope: what sort of data are to be collected; $;^{98}$

(2) Focus of the gaze (within scope of collection): what sort of data collected are to be emphasized and what data are to be discarded or ignored $;^{99}$

(3) Capacity for collection: this is an issue of technological capacity-how can data be harvested; how much can be harvested; what are the limits of data harvesting; ${ }^{100}$ and

(4) Analytical framework: how data are to be interpreted or put together, and how data are to be framed given the objectives underlying their collection. ${ }^{101}$

98. An excellent recent example of this issue arises in the context of the regulation of corporate activity. Under traditional surveillance regimes, economic entities are usually required to report only financial data. But that privileges a view of corporate activity centering on its economic performance as measured by the data to be supplied. Where additional data are collected-for example on entities' social and environmental activities, the focus of both reporting and corporate conduct may be affected. See Larry Catá Backer, From Moral Obligation to International Law: Disclosure Systems, Markets and the Regulation of Multinational Corporations, 39 Geo. J. INT'L L. (forthcoming 2008).

99. The recent controversy over the extent of reporting of executive compensation is a case in point. Though corporations report financial data, that reporting may focus on some areas and ignore or hide others. That produces incentives and opportunities to engage in strategically advantageous behavior. See, e.g., Roel C. Campos, Commissioner, SEC, Remarks Before the 2007 Summit on Executive Compensation (Jan. 23, 2007) (available at http://www.sec.gov/news/speech/2007/ spch012307rcc.htm) ("I'm sure that some are hopeful that the new disclosure rules will have the effect of lowering CEO compensation, and that might be the case, but I'm not sure. Laws and rules have curious unintended consequences." Id.).

100. Surveillance is keenly dependent on technology in both qualitative and quantitative terms. But it goes farther than that. Technology also affects the ease with which harvested information may be utilized. The recent efforts to keep track of computer communications provides a telling case in point. See, e.g., Geoffrey A. North, Carnivore in Cyberspace: Extending the Electronic Communications Privacy Act's Framework to Carnivore Surveillance, 28 Rutgers Computer \& Tech. L.J. 155 (2002). See generally The Carnivore Controversy: Electronic Surveillance and Privacy in the Digital Age: Hearing Before the Comm. on the Judiciary, 106th Cong. (2000).

101. The reasons for collecting data, of course, significantly affect the character of the information collected, processed and used. See, e.g., United States v. United States Dist. Court, 407 U.S. 297 (1972) ("Moreover, we do not hold that the same type of standards and procedures prescribed by Title III are necessarily applicable to this case. We recognize that domestic security surveillance may involve different policy and practical considerations from the surveillance of 'ordinary crime.'... Given these potential distinctions between Title III criminal surveillances and those involving the domestic security, Congress may wish to consider protective standards for the latter which differ from 
Each of these factors affects the character of the information to be produced, the aggregate shape of the data collected, and the likely shape of the "outcomes" of harvesting for whatever judgment is to be made or whatever sets of behaviors are to be applauded or condemned. The determination of scope, focus (inclusion and exclusion), capacity, and framework, affects the way in which the monitor and monitored approach a valuation of appropriate behavior.

\section{From Data to Information Evaluation}

Related to recognition and collection issues are use issues relating to data (judgment). Identification and production serve as the foundation for utility, for the use of knowledge. This is the power of power/knowledge..$^{102}$ Data are inert until used. ${ }^{103}$ Though the identification and harvesting of knowledge implicates judgment (and use), that use remains contingent until the active element is introduced. That active element blends time and agency. Data can sit for long or short periods of timesubject to the technologies of preservation and retrieval. Information use is contextual-who uses it in what cultural context colors the importance and character of the information at the moment of its deployment. That use is not merely consequential - it serves as the essence of the governance element of surveillance. This characteristic of making judgments and deploying those judgments within the community under observation can be understood as governance. ${ }^{104}$

those already prescribed for specified crimes in Title III." Id. at 322). Though teased out in the language of law, these are the issues at the heart of the surveillance debates in the wake of the terrorist attacks on the United States on September 11,2001. See, e.g., Diane Marie Amann, Punish or Surveil, 16 Transnat'l L. \& Contemp. Probs. 873 (2007); Robert M. Chesney, State Secrets and the Limits of National Security Litigation, 75 Geo. WAsh. L. Rev. 1249 (2007). See generally Adam D. Moore, Toward Informational Privacy Rights, 44 San Diego L. Rev. 809, 838-39 (2007).

102. The information management field is well aware of this insight that has yet to penetrate law to any useful extent. "In the past, systems for business have focused on selected data within a certain context to produce information. A better approach is to take information accompanied by experience over time to generate important knowledge. In addition, knowledge that is renewed and enhanced can be a creative source to outmaneuver competition." Robert J. Thierauf, Knowledge ManageMENT Systems for Business vii (1999). The author, for example, constructs a hierarchy of knowledge that effectively applies the knowledge/power dynamic. Data are identified as "[u]nstructured facts," information as "[s]tructured data useful for analysis," knowledge is described as "[o]btained from experts based on actual experience," wisdom is defined an "[a]bility to judge soundly," and truth is understood as "[c]onformance to fact or reality." $I d$. at 6.

103. But recall that data themselves can also constitute a product of judgment, that is, data themselves itself represent a judgment about what constitutes a "fact" or discrete data. See discussion supra Part III. A.

104. See discussion infra Part IV. D. 
Use issues revolve around the problem of the conversion of data into information. This suggests that there is a two-way relationship between data-its aggregate construction and the purposes/principles to be furthered by the surveillance exercise. Use problems are grounded in issues of sufficiency, each of which affects capacity in different ways. These include:

(1) Verification: confirmation, corroboration, and confirmation of a condition, effort, or authenticity of assertions. Verification, for example, was a primary use objective of information gathering in Iraq before the U.S. invasion in 2003. ${ }^{105}$

(2) Management: assessment or basis for making decisions touching on the organization, staffing, and internal operation of the entity. Information gathering for use in employee evaluation, for example, or for the evaluation of any product, system or condition touches on the evaluative function of information. ${ }^{106}$

(3) Exposure: disclosure, transmission, dissemination, or privileging of particular facts going to issues of fundamental importance to the operation or management of the entity. Exposure of wrongdoing may provide the basic objective of information and its use-for example littering, drug use in parks, or sex in public bathrooms. ${ }^{107}$ Compliance with obligations has been an increasingly useful objective of information gathering on the behavior of multinational corporations by non-governmental organizations and other informal monitors of enterprise activity. ${ }^{108}$

(4) Confession: affirmation, acknowledgement of a judgment, condition, or action. The monitoring aspects of American securities law, for example, are riddled with the technique of confession. ${ }^{109}$

105. See, e.g., Kathleen C. Bailey, The UN Inspections in IraQ: Lessons for On-Site VerifiCATION (1995).

106. See, e.g., Kristie Ball, Categorizing the Workers, Electronic Surveillance and Social Ordering in the Call Center, in Surveillance as Social Sorting: Privacy, Risk, and Digital Discrimination 201 (David Lyon ed., 2002).

107. See, e.g., David Brin, The Transparent Society: Will. Technology Force Us to Choose Berween Privacy and Freedom? (1998).

108. See Larry Catá Backer, Multinational Corporations as Objects and Sources of Transnational Regulation, 14 ILSA J. INT'L Comp. L. (forthcoming 2007-2008).

109. Certifications, affirmations, and other swearing mark the principal documents used to register securities, to periodically report on the financial status of the registrant, and especially under the provisions of the Sarbanes Oxley Act, to attest to the financial condition of the company and critically, under Section 404 of the Sarbanes Oxley Act, to attest to the functioning of the internal 
Lastly, data harvesting implicates surveillance system issues. There is an objective element--touching on the sufficiency of data generated-and there is a relational element-focusing on the relationship of information put together from data generated related to the judgment to be made. It also looks to the connection to principles/purposes to be furthered. In this aspect, data harvesting intersects with issues of surveillance normativity. This is especially the case where issues of legitimacy of methodology arise. ${ }^{110}$

\section{Dissemination of Information}

Information utility requires a system for the useful harvesting of data. That requires turning data into information suitable for a particular purpose. But surveillance has an active as well as a passive element. That active element requires broadcasting of information to an appropriate range of recipients. Information is power not merely for the persons collecting data, or for those charged with its evaluation, but also for those who receive data or its products and can act on the basis of the information received. Information is, in this sense, a commodity with a certain value. That value may depend on its scarcity.

The information hierarchies and power relationships implicit in the system of secret information nicely illustrates the relationship between information and its

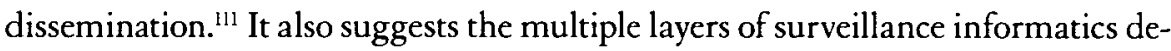
scribed in this part. Data, information, and the power to evaluate information are objects of power. To be eligible for top secret clearance requires conformity to a set of exacting norms and behaviors, the reward for which is access to information that is itself a gateway to governance power. There is a positive correlation between status, power, and access to information.

The converse is true as well. Transparency has been an effective tool for democratization as well as for broadening the class of persons who might be able to

system of surveillance from which data is drawn for both private purposes (participation by private stakeholders) and public purposes (regulatory control by the state). See Sarbanes-Oxley Act of 2002, supra note 8; Larry Catá Backer, The Sarbanes-Oxley Act: Federalizing Norms for Officers, Lawyer and Accountant Behavior, 76 ST. JoHn's L. Rev. 897 (2002).

110. See discussion supra Part II.A.

111. See Further Amendment to Executive Order 12958, As Amended, Classified National Security Information, available at http://www.whitehouse.gov/news/releases/2003/03/20030325-11 .html (prescribing "a uniform system for classifying, safeguarding, and declassifying national security information"). The system is based on an acceptance of the idea that "[p]rotecting information critical to our Nation's security remains a priority." Id. 
act on information. The efforts of non-governmental organizations- monitoring the behavior of multinational corporations and producing reports of their monitoring activities that are published in the media — have been a powerful method of regulating the behavior of multinational enterprises without recourse to law. ${ }^{112}$

\section{Surveillance as Control}

The control aspect of surveillance is tied to the judgment aspect of knowledge production, but it also tends to change the understanding of knowledge. More importantly, it changes the dynamics of the harvesting of information for its use in producing judgment and control..$^{113}$ There is little in the private/public divide suggested by legal systems in the intervention of surveillance in the production and construction of knowledge. ${ }^{114}$ Thus, monitoring regimes in the policing of securities markets have acquired a cross-border dimension as well as a fracturing of surveillance power between public and private entities. ${ }^{115}$ In another context, the

112. Consider for example the work of the non-governmental organization, Transparency International, "a global network including more than 90 locally established national chapters and chapters-in-formation. . . . Politically non-partisan, TI does not undertake investigations of alleged corruption or expose individual cases, but at times will work in coalition with organisations that do." Transparency International, About $U s$, http://www.transparency.org/about_us. Transparency International is known for a number of indexes it publishes based on information it receives and processes on various aspects of corruption. These include the "TI Corruption Perceptions Index (CPI), first released in 1995, [and] the best known of TI's tools. It has been widely credited for putting TI and the issue of corruption on the international policy agenda. The CPI ranks more than 150 countries in terms of perceived levels of corruption, as determined by expert assessments and opinion surveys." Transparency International, Tools, Measurement, http://www.transparency.org/ tools/measurement. They also publish a Bribe Payors' Index. Id.

113. See William I. Miller, The Anatomy of Disgust (1998).

114. See generally Louis W. Pauly, Who Elected the Bankers? Surveillance and Control in THE World Economy (1997).

115. See Kalypso Nicolaidis \& Gregory Shaffer, Transnational Mutual Recognition Regimes: Governance Without Global Government, 68 Law \& Contemp. Probs. 263, 280 (2005).

Hybrid public-private administration is widespread in mutual recognition regimes, which can involve the outsourcing of monitoring, certification, and assessment functions. For example, in the U.S.-E.U. 'safe harbour' negotiations over the recognition of privacy standards, the E.U. member states' data privacy authorities met with BBB OnLine, a private U.S. entity, to see how its certification works within the U.S. context. When European authorities became more comfortable with U.S. oversight mechanisms that involve private entities backed by potential enforcement by the U.S. Federal Trade Commission, they agreed to the transatlantic Safe Harbor understanding. 
media are an industry with political implications, as well as reproducing culture, selectively representing the world, and selling goods and services. The media act in subtle, indirect, and direct ways as conduits of social control, surveillance, monitoring, and classification. They are a fundamental mechanism in active social control, i.e., the selective enforcement of norms through sanctioning in a network of communicants. ${ }^{116}$

These ideas are bound up in the concept of synecdoche. ${ }^{.17}$ Grounding action through surveillance in the notion that the part (observed) can represent the whole (whether or not observed) transforms the techniques of observation (data gathering) into performative and symbolic roles. It transforms the observed into a representation of the whole of the observable. And on that basis, it turns the observed into the basis for judgment. Judgment in this sense, is understood in its regulatory dimension. This is surveillance in its aspect as "power applied" to control. It invokes a distribution element as well.

The control aspect of surveillance can be divided into four substantive elements: (1) Who may determine what information must be produced and what judgment may be made from the information thus produced; (2) Who must produce information; (3) Who may make use of the information (who is the beneficiary of the information-direct and indirect); and (4) How can it be used-the heart of the regulatory aspect of this set of surveillance components. Each is discussed in turn.

\section{A. The Power to Determine the Contours of Information Production}

The question of control of information production and the normative basis of judgment has not been sufficiently studied, but the outlines of the problems for law and governance appear fairly clear. At the most parochial level, investing data harvesting with significance increases the power of the information gatherer and

116. Peter K. Manning, Reflections: The Visual as a Mode of Social Control, in MAKING Trouble: Cultural Constructions of Crime, Deviance, and Control 255, 259 (Jeff Ferrell \& Neil Websdale eds., 1999) [hereinafter Making Trouble].

117. The origins of the term are in rhetoric. See Giambattista Vico, The Art of Rhetoric 143 (Institutiones Orratoriae, 1711-1741) (Giorgio A. Pinton \& Arthur Shippee eds. \& trans., 1996). For a useful discussion of the concept of synecdoche, see Daniel Chandere, Semiotics: The BAsics 132-34, 243-44 (2002). 
the institutions of data collection that the gatherer controls. ${ }^{118}$ Control of the choice of data to be collected is the foundational power of surveillance. This power tends to affect not only the obligations of those under observation and the data gatherers, but also the parameters of conceptualization of the "issue" and its possible solution. In a sense, the choice of data is the basic building block of surveillance as a regulatory vehicle.

Consider an easy example-accounting principles. Generally Accepted Accounting Principles (GAAP) ${ }^{119}$ and Generally Accepted Auditing Standards (GAAS) ${ }^{120}$ provide a universe of definitions of the meaning of economic activity and the methods by which they may be conceived and reported, in line with a meta-conceptual system centered on the meaningfulness of financial statements. Control of GAAP has extraordinary effects on the way business is understood, and therefore on the way business is organized, and to some extent, on the way in which it may consider business decisions (at least with respect to their effects of the corporation's financial statements). Control of GAAP, in the United States, traditionally has been in the hands of the accounting profession. ${ }^{121}$ In the European Union, the state has traditionally controlled the meaningfulness of data.

Since the enactment of the Sarbanes-Oxley Act, ${ }^{122}$ the United States government has sought to take an increasing amount of control over the meaningfulness and judgment value of data from private self-regulatory groups. These shifts in control can have significant effects on the reality of business as presented through their financial statements. And control of that reality has normative political and

118. Consider Matthew M. Mason, Meeting the Challenges of Data Collection in Outcome Systems, 23 Education \& Treatment of Children 75, 79 (2000):

The measurement of outcomes has wider reaching effects on agencies than may first be anticipated. Initially, outcome measurement may be pegged as a quality control function, or be described as a program improvement process.... Frequently, what was meant as an add-on activity to one or two staff member's jobs grows to influence and involve numerous people, including leadership, development, clinical, financial, recruiting, direct and indirect care personnel.

119. For a history of GAAP, see Financial Accounting Standards Board, http://72.3.243.42/ project/gaap_hierarchy.shtml (last visited Feb. 14, 2008).

120. For a history of GAAS, see Robert Tie, The New World of Auditing Standards: A Conversation with the $A S B$, J. Accr., May 2006, at 59.

121. These include the Financial Accounting Standards Board (FASB), which has been designated, since the 1970 s, by the SEC as the organization charged with setting accounting standards for the public interest. See FASB, http://www.fasb.org/facts (last visited Sept. 10, 2007). The history of contests for power to control the meaning of accounting data is itself an excellent window on the normative nature of surveillance. See Robert Van Riper, Setting Standards for Financial Reporting: FASB and the Struggle for Control of a Critical Process (1994).

122. Sarbanes-Oxley Act of 2002, supra note 8 . 
economic effects. Thus, for example, a high priority between the United States and the European Union has centered on an attempt to bring control of GAAP into government hands and to seek to harmonize the meaning of those terms for the mutual benefits of both. ${ }^{123}$ By controlling the content and methods of financial disclosure, government would also seek to control those actions which are to be encouraged and those which are not. In this way, the behavior of economic entities will be effectively controlled-by reference to the privileging and marginalization of behaviors represented in the systems of accounting disclosure, without the bother of controlling conduct through direct legislation. Control of the power to determine these standards thus has significant political effect.

The question of the nature of the judgment that may be made from the information thus produced is harder. This suggests a relationship between data and "policy." Data tends to be collected for a set of specific objectives in furtherance of a particular cluster of policy. ${ }^{124}$ The choice of data collected, and the meaning extracted from that data, is grounded in this synthesis of data, objectives, and policy.

123. This would include the work of the International Accounting Standards Board:

The International Accounting Standards Board is an independent, privately-funded accounting standard-setter based in London, UK. The Board members come from nine countries and have a variety of functional backgrounds. The IASB is committed to developing, in the public interest, a single set of high quality, understandable and enforceable global accounting standards that require transparent and comparable information in general purpose financial statements. In addition, the IASB co-operates with national accounting standardsetters to achieve convergence in accounting standards around the world.

International Accounting Standards Board, About IASB, http://iasb.org (follow "about us" hyperlink, then follow "About IASB" hyperlink) (last visited Feb. 14, 2008). See also Melvin Houston \& Alan Reinstein, International Accounting Standards and Their Implications for Accountants and U.S. Financial Statement Users, Rev. Bus., Summer 2001, at 75. But harmonization remains to be fulfilled within the European Union itself. Accounting data is thus a particularly useful field in which to understand the difference between data and meaning, between information and judgment. See Susan M. Sorensen \& Donald L. Kyle, Found in Translation: A Guide to Using Foreign Financial Statements, 203 J. Accr, Feb. 2007, at 38.

124. The information gathering apparatus and techniques of the "War on Terror" provide an excellent example. Data is chosen, techniques developed, and the scope of the gathering efforts determined in light of the objectives-not a scholarly determination of the character and nature of terrorism, or of the assessment of information for the purpose of determining what constitutes terror, but focused on a cluster of "enemies" already identified who engage in tactics and objectives already understood. See Seth F. Kreimer, Watching the Watchers: Surveillance, Transparency and Political Freedom in the War on Terror, 7 U. PA. J. Const. L. 133, 149-69 (2004) (“A political establishment that systematically tracks the involvement of particular individuals in political support or opposition is a political establishment that can move to reward supporters and punish critics," citing to that old adage from organizational theory, "you manage what you measure" in Louis Low- 


\section{B. Assigning Responsibility for the Production of Information}

Yet, the question of who must produce information is harder still. This implicates both the objects of policy and the power to organize institutions for the generation or harvesting of particular sets of data. In some respects the power to subject a person or entity, event, or occurrence to observation is as important as the power to choose among data to harvest. This is a power to impose a regulatory regime beyond the traditional juridico-legal regimes of traditional society on which state authority had been built. ${ }^{125}$

\section{Who May Make Use of Information}

Defining the classes of actors who may make use of the information (who is the beneficiary of the information-direct and indirect) presents additional difficult issues of law, policy, and governance. To a large extent, this is the question usually framed in terms of the objectives of the observation and the class of persons or things against which observation and reporting is necessary. Yet, this-implicates power more than policy. The reference is not to the ordinary sort of power, understood as the exercise of legitimate political power, but to power understood as the holder of a control over data that is desired. That control can be held easily by a private organization that has access to information. ${ }^{126}$

\section{How May Information be Used}

Lastly, the objectives for which information harvested may be used present the most difficult question. This last consideration forms the heart of the regulatory aspect of this set of surveillance components. The focus of the control issues in surveillance is bound up with the institutionalized systems through which data is produced and bundled as judgments - that is, as conclusions. It also is focused on the use of data to verify, manage, expose, or induce confession. The control element thus cen-

enstein, Financial Transparency and Corporate Governance: You Manage What You Measure, 96 Colum. L. Rev. 1335, 1342-43 (1996)).

125. See generally Foucault, supra note 52, at 89-96; Foucault, supra note 32, at 195-228.

126. These might include rating agencies, including those who can obtain data that is already in circulation and those which can coerce data because of the perceived legitimacy of the gathering and judging that the organization produces. Consider in this sense the country assessments of both Amnesty International, http://www.amnesty.org, and of the International Monetary Fund, http:// www.imf.org. 
ters on the system aspects of surveillance. This system aspect forms the most visible basis of the regulatory function of surveillance. Systems reify control based on the elements of information gathered and judgments privileged on the basis of the values framework through which surveillance is elaborated. Content, technique, and discipline conflate and find expression through surveillance framework, thus providing the means for enforcing the regulatory ends of surveillance.

This control element has both an upstream and a downstream vector. The upstream vector encompasses elements of internal institutional control-that is, of self-control. The object is internal discipline. The beneficiaries of this form of surveillance are the internal stakeholders of the organization-employees and officers or organizations - or political subdivision - the bureaucrats and other staff that work for the apparatus of state. But the object also benefits external stakeholders closely associated with the organization-investors in the private sector and voters in the public sector.

The origins of the techniques and normative basis may develop at one or more levels. For example, it may be developed internally by the entity engaged in surveillance. ${ }^{127} \mathrm{Or}$ it may develop by the community of entities for which surveillance is meant to aid in internal governance and to discipline the community of entities into privileging a uniform set of norms reflected in the objects of surveillance and the data sets monitored. ${ }^{128}$ It might also be developed by a superior pub-

127. The usual example is the internal monitoring systems of public corporations. See, e.g., Donald A. Marchand et al., Making the Invisible Visible: How Companies Win with the Right Information, People and IT (2001). See also Lowenstein, supra note 124. Usually tied to that internal monitoring are notions of stakeholder monitoring of corporate activity. See Larry Catá Backer, The Duty to Monitor: Emerging Obligations of Outside Lawyers and Auditors to Detect and Report Corporate Wrongdoing Beyond the Federal Securities Laws, 77 Sr. John's L. Rev. 919 (2003), reprinted in 53 DEF. L.J. 671 (2004) (focusing on monitoring obligations of outside auditors and corporate counsel). Recently, stakeholder monitoring has begun to extend well beyond the usual group of shareholders and professional advisors. See, e.g., Tom Baker \& Sean J. Griffith, The Missing Monitor in Corporate Governance: The Directors' and Officers' Liability Insurer, 95 Geo. L.J. 1795 (2007).

128. The usual example is the trade associations to which members of a particular industry may belong, and which may, for the benefit of all of its members, collect data for private or public consumption. See generally Leonard H. Lynn \& Timothy J. McKeown, Organizing Business: Trade Associations in America and Japan (1988). In this light, consider the National Retail Federation, which "is the world's largest retail trade association, with membership that comprises all retail formats and channels of distribution." National Retail Federation, Home Page, http://nrf.org/ (last visited Feb. 28, 2008). See also National Retail Federation, Mission Statement, http://nrf.org/ modules.php? name $=$ Pages $\&$ sp_id $=146 \&$ pmenu_id $=1 \&$ mn_type $=1$ (last visited Feb. 28,2008 ). Its associated NRF Foundation "conducts industry research, develops education and workforce development programs, and promotes retailing as a career destination." Id. The research includes industry benchmarks, demographic data, and public policy analysis. See NRF Foundation, Indus- 
lic regulatory community, ${ }^{129}$ or by private regulatory organizations with influence over an important segment of the surveillance entity's business. ${ }^{130}$ The techniques, scope, focus, and normative framework of surveillance will differ depending on the origins and control of the surveillance framework. Surveillance becomes complicated when an entity internalizes multiple, partial scope surveillance frameworks.

The downstream element encompasses elements of external control by/through others. The object is external discipline. The beneficiaries of surveillance in this form include a number of actors. One class of beneficiaries are political communities--home state, host state, local communities, and supranational communities. Control systems originate in statute. Another group of beneficiaries includes outside stakeholders, including labor, lenders, and trade creditors. Downstream control systems originate in contract. The contract basis of observation permits the participation of a host of private actors. These include affinity groups, for example civil society and non-governmental organizations. The origins of the techniques and normative

try Research, http://www.nrf.com/content/default.asp? folder = foundation\& file = research.htm (last visited Feb. 28, 2008). The last is particularly interesting, as a group of "accurate statistical information that informs legislators, the media, and other decisions makers how their actions will impact consumers, retailers, and the economy." Id.

129. An example can be found in the various money laundering acts that have become a staple of regulation in many countries. These tend to impose on banks a substantial body of surveillance and reporting obligations with respect to certain financial transactions (but not all such transactions) to which the state gaze is turned. "In sum, anti-money laundering and terrorist financing initiatives have provided political impetus for many jurisdictions to increase the monitoring and responsibilities of banks, to exchange financial information with other countries, and even to allow tax authorities to access financial information reported for money laundering purposes." Suzanne Walsh, Note, Taxation Of Cross-Border Interest Flows: The Promises And Failures Of The European Union Approach, 37 Geo. WASh. Int'L L. Rev. 251, 289 (2005). See also Joseph J. Norton \& Heba Shems, Money Laundering Law And Terrorist Financing: Post-September 11 Responses - Let Us Step Back And Take A Deep Breath?, 36 Int'L Law. 103 (2002).

130. Product certification programs, based on contractual arrangements under which corporations or other merchants may display a logo indicating certification of compliance with any one of a number of requirements with respect to, for example, the use of recycled paper products, or the payment of a living wage, verified through a program of self reporting and monitoring of compliance. For an example of the mechanics of product certification, see Fair Trade Certified, About Fair Trade, http://transfairusa.org/content/about/index.php. Fair Trade Certification "guarantees consumers that strict economic, social and environmental criteria were met in the production and trade of an agricultural product. Fair Trade Certification is currently available in the U.S. for coffee, tea and herbs, cocoa and chocolate, fresh fruit, flowers, sugar, rice, and vanilla. TransFair USA licenses companies to display the Fair Trade Certified label on products that meet strict international Fair Trade standards." Id. 
basis of this form of surveillance may develop at one or more levels, in a manner that parallels that in upstream disclosure.

An issue common to both upstream and downstream surveillance systems involves generation versus transmission. Both upstream and downstream surveillance systems distinguish between generation and transmission of information, either as "raw data" or "judgment." Not all data/information generated is transmitted. For example, data generated for internal management may not all be made available to government regulators. Not all data/information transmitted is redelivered in the same form or with the same content to different sets of recipients. For example, internal financial accounting systems may differ from financial reporting under Reg. S-X (SEC). ${ }^{131}$ Moreover, not all data/information transmitted is generated from the same source. For example, in the securities industry, data generators may be different from data bundlers (analysts). ${ }^{132}$ Lastly, both upstream and downstream surveillance systems distinguish between passive and active elements. This invokes the power element of surveillance. Active elements require information and may affect its meaning, content, and scope. Passive elements do not. Yet, both affect the substantive element of surveillance. Insiders seeking information for the attainment of management goals will understand data in a way different from insiders seeking information for the attainment of production goals.

\section{Surveillance as Governance}

"The proliferation of quantitative measures of performance is a significant social trend that is fundamental to accountability and governance; it can initiate sweeping changes in status systems, work relations, and the reproduction of inequality." 133 That idea, so well understood in the traditional social science literature, also has significant implications for political governance. Consider the complex of power issues involved in the construction of transnational transparency regimes of financial markets. Entities like the International Monetary Fund and

131. See, e.g., Nilabhra Bhattacharya et al., Empirical Evidence on Recent Trends in Pro Forma Reporting, 18 Acct. Horizons 27, 28 (2004) (noting the arguments in favor of non GAAP pro forma reporting as a means to "demystify complex accounting disclosures and provide a clearer picture of the 'core earnings' that they expect to persist in future periods"). The results are even more pronounced between tax accounting and financial accounting regimes. See Celia Whitaker, Bridging the Book-Tax Accounting Gap, 115 YALE L.J. 680 (2005).

132. This is likely the result under the new MiFID directive as it is transposed into the national law of the Member States in the European Union. See Backer, supra note 50.

133. Espel \& Sauder, supra note 56, at 2. 
World Bank "have found themselves drawn into battles with a range of transnational, multinational, domestic, and international authorities over the production of financial information and the diffusion of financial information." ${ }^{34}$

In this aspect, surveillance is felt as gouvernmentalité, a linking of governance with the techniques of its power. ${ }^{135}$ Policing appears to have become a primary focus of governance. In this respect, the Sarbanes-Oxley Act ("SOX"), ${ }^{136}$ for example, can be considered an excellent example of gouvernmentalité. It sought to legislate an architecture of corporate discipline, and from that discipline, to develop and impose substantive behavior norms tied to the forms of externally imposed self-discipline. ${ }^{137}$ That architecture of corporate discipline--essentially hierarchical, continuous, and integrated within the core of the institutional governance architecture, ${ }^{138}$ like Jeremy Bentham's Panopticon, ${ }^{139}$ defines a structure of information gathering centrally focused on corporate directors who are required to "see" everything. Yet these seers are themselves "seen" by the ultimate regulator. That ultimate regulator, the federal government, selects the data to be gathered ${ }^{140}$ deploys corporate outsiders to monitor internal surveillance efficien-

134. Margaret Hansen, The Global Promotion of Transparency in Emerging Markets, 9 Global Governance 63, 64 (2003) ("These political battles cast a critical light on seemingly apolitical assumptions that motivate much of the theoretical rationale for international governance strategies inspired by the goal of a transparent global financial system.").

135. Foucault, supra note 6, at 67-71 ("One of the most notable features of governmentality research has been its investigation of power 'beyond the state,' that is, with the tactics, techniques and technologies which configure apparently 'non-political' sites like the firm or the school as spaces of power."); Wendy Larner \& William Walters, Introduction: Global Governmentality, in Global Governmentality: Governing International Spaces 1, 1 (Wendy Larner \& William Walters eds., 2004) [hereinafter Global Governmentality].

136. Sarbanes-Oxley Act of 2002, supra note 8.

137. In its essence, the Sarbanes-Oxley Act of 2002 is about disclosure. Crafted by Congress in the aftermath of financial collapses at corporations like Enron, Global Crossing and WorldCom, the new law establishes the framework for a new regime of accountability by public companies in the areas of financial reporting and disclosure, audits, conflicts of interest and governance.

Jenny B. Davis, Sorting Out Sarbanes-Oxley: Determining How to Comply with the New Federal Disclosure Law for Corporations Won't be Easy, ABA J. 44 (Feb. 2003).

138. For a description of the architecture of surveillance generally, see Backer, supra note 55. For a discussion of the surveillance within the SOX architecture focusing on the monitoring obligations of auditors and outside counsel, see Backer, supra note 127.

139. Jeremy Bentham, Panopticon, or, The Inspection House, (1787), reprinted in The Panopticon Writings 29, 29-95 (Miran Božovi ed., Verso 1995) (1791).

140. Thus, the focus of securities law tends to gravitate to the nature and quality of disclosure as a proxy for the underlying values such disclosure represents. Disclosure-the techniques of the gaze, substitute for the traditional formal concentration on substantive outcomes. Surveillance becomes the means of governance and law serves as its mechanics. An excellent recent example is 
cies, defines the boundaries of effective analysis (that is of analysis with legal effects), and selects the judgment to be made from certain clusters of information, but not from others. ${ }^{141}$ Corporate insiders, like Bentham's theoretical prisoners, can most effectively and economically "always feel themselves as if under inspection, at least as standing a great chance of being so."142 Yet, at the same time, "the emerging matrixes of surveillance and control, more clearly revealed and articulated by SOX, also reveals something far more significant: A shift from a market to a governmental system for developing behavior norms within firms and for disciplining actors who violate those norms." ${ }^{.43}$

Gouvernmentalité thus implicates the consequences of adjustment of elements of the normative, informatics, and control aspects of surveillance. In a sense, it describes lawmaking in a new form. ${ }^{144}$ "Since the dissolution of the geopolitics of the Cold War the security politics of global liberal governance has come to depend extensively upon risk, insurance, surveillance, criminalisation and the

provided over the debates concerning disclosure of executive compensation in the aftermath of the Disney-Ovitz litigation. See Securities \& Exchange Commission, Final Rule: Executive Compensation and Related Person Disclosure, 71 Fed. Reg. 53158 (Sept. 8, 2006) (to be codified at 17 C.F.R. pts. 228. 229 et al.). For a discussion of the Disney-Ovitz litigation, see Harvey L. Pitt, The Changing Standards by Which Directors Will Be Judged, 79 Sr. John's L. Rev. 1, 5-7 (2005) (reviewing the Disney litigation in light of the prevalent issue of executive compensation in corporate America); Charles M. Yablon, Bonus Questions-Executive Compensation in the Era of Pay for Performance, 75 Notre Dame L. Rev. 271, 274 (2000) (examining the Disney cases as they relate to the growing problems with executive compensation in an "era of performance-based pay"); Larry Catá Backer, Director Independence and the Duty of Loyalty: Race, Gender, Class and the Disney-Ovitz Litigation, 79 ST. JoHN's L. Rev. 1011 (2005) (considering the duty of loyalty issues in compensation cases like that involved in the Disney-Ovitz litigation).

141. This becomes clear from the continuing refinements of the surveillance structures imposed through SOX. See, e.g., Securities \& Exchange Commission, Definition of the Term Significant Deficiency, 72 Fed. Reg. 44924 (Aug. 9, 2007) (refining the meaning of the term "significant deficiency" for purposes of the Commission's rules implementing Section 302 and Section 404 of the Sarbanes-Oxley Act of 2002 (the reporting obligations)).

142. Bentham, supra note 139 , at 43. "What is also of importance is, that for the greatest proportion of time possible, each man should actually be under inspection. This is material in all cases, that the inspector may have the satisfaction of knowing, that the discipline actually has the effect which it is designed to have: and it is more particularly material in such cases where the inspector, besides seeing that they conform to such standing rules as are prescribed, has more or less frequent occasion to give them such transient and incidental directions as will require to be given and enforced, at the commencement at least of every course of industry." Id. at 44.

143. See Backer, supra note 55, at 331.

144. For a discussion of one form of this new information-based regulatory system, see Bradley C. Karkkainen, Information as Environmental Regulation: TRI and Performance Benchmarking, Precursor to a New Paradigm?, 89 GEo. L.J. 257 (2000-2001). 
vernacular of street architecture to shape rational behaviour by empowering security-conscious subjectivities. ${ }^{145}$ Regulation presents itself, in its new form, as an inversion of traditional regulation. Law is not supported by surveillance as a mechanics of enforcement. Instead, the mechanics of enforcement are supported by law that serves as the mechanics of surveillance as a substantive pronouncement. Law, as surveillance, is thus transformed into judgments derived from what is chosen to be observed, recorded, analyzed, packaged, and constituted as reality, which produces legal, social, political, and economic effects. One encounters here regulation beyond the state and beyond politics.

Gouvernmentalité also serves as a bridge between surveillance as technique and the systemic replication of private desire in collective action. In this aspect, one focuses on the consent of the actors in systems of surveillance used to reinforce or articulate normative systems of power and behavior. "Governing people, in the broad meaning of the word, governing people is not a way to force people to do what the governor wants; it is always a versatile equilibrium, with complementarity and conflicts between techniques which assure coercion and processes through which the self is constructed or modified by himself." ${ }^{146}$ Thomas Lemke ${ }^{147}$ notes that "the analysis of gouvernmentalité does not only take into account 'breaks' or 'gaps' between program and technology, but also inside each of them-viewing them not as signs of their failure but as the very condition of their existence." Thus, "government refers to a continuum, which extends from political government right through to forms of self-regulation, namely technologies of the self."148

Gouvernmentalité can thus also be understood in its Aristotelian sense, as a necessary self-replication of normative understanding and techniques from out of the individual to the collective. ${ }^{149} \mathrm{~A}$ full array of issues commonly understood as democratic accountability and democratic action are also bundled in this regard. These may be understood as norms and procedure and touch on issues of who ought to compel surveillance, who may be monitored, the complications of self-surveil-

145. Michael Dillon, The Security of Governance, in Global Governmentality, supra note 135, at 76,80 .

146. Michel Foucault, About the Beginning of the Hermeneutics of the Self: Two Lectures at Dartmouth, 21 PoL. Theory 198, 204 (Mark Blasius ed., 1993).

147. Thomas Lemke, Foucault, Governmentality and Critique, Paper presented at the Rethinking Marxism Conference at the University of Amherst (MA) (September 21-24, 2000), http://www .thomaslemkeweb.de/publikationen/Foucault, \%20Governmentality, \%20and\%20Critique $\% 20 I V-2$.pdf, at 9-10.

148. Id. at 12.

149. Aristotle, Politics, available at http://www.gutenberg.org/etext/6762. 
lance, the connection between monitor and monitored, beneficiaries along the stream of conveyance of data/information from construction to broadcast, and political power and democratic accountability (that is of private recourse to the normative framework of public accountability). Indeed, the techniques that constitute surveillance empower political action against the apparatus of political authority in states, as well as enabling that power to extend its reach. It has been used as both a method of participation in and of resistance to governance. For example, the control of crowds and mass protests through the techniques of surveillance has been met by evolving techniques of resistance based on the same techniques deployed to control crowds. ${ }^{150}$ The techniques developed for crowd control-and thus for the control (or management) of political expression acceptable to the governing ideology (whether democratic, Marxist, theocratic, or otherwise) have been adapted by those who seek to resist that control. ${ }^{151}$ Likewise, global NGOs have used surveillance and disclosure as methods of enforcing corporate regulatory regimes between multinational corporations, like Gap, Inc. and its global suppliers. ${ }^{152}$ Surveillance thus sharpens and disperses regulatory power in new ways. And individual participation is both broadened and made more complex.

Ultimately, surveillance here in its normative/regulatory guise confronts the issues: Is there an ideal from which deviations can be judged? And at what point is deviation severe enough to merit discipline and correction? The answer increasingly appears to be no ... and yes! There is a diminishing likelihood that a single ideal will serve as the basis for constructing the fact set from which deviation ought to be judged. However, as governance systems fracture and governance power seeps from political to ethnic, economic, religious, and affective communities, which together form multi-layered and networked communities, it is likely that the techniques of surveillance will serve as the connection between individual self-constitution and the constitution of governance systems in its substantive and disciplinary aspects.

150. One of the techniques recently developed by protest and political/social action movements, has been "swarming," "the dispersion of command among many small, autonomous units." Institute for Applied Autonomy, Defensive Surveillance: Lessons From the Republican National Convention, in Surveillance and Security: Technological Politics and Power in Everyday Life 167, 168 (Torin Monahan ed., 2006).

151. "This is accomplished by 'comms affinity groups,' which are collections of technically savvy activists who are responsible for intelligence gathering and information dissemination during protests." Id. at 169. Observation and communication is accomplished by the fusion of a variety of technologies: "two-way radios, cell phones, the Internet, radio, and word of mouth. During the $\mathrm{RNC}$, comms groups relied on cell phone text messaging to an extent previously unrealized during highly anticipated mass mobilizations." Id.

152. See Backer, supra note 108 . 


\section{Putting it all together}

Surveillance, understood as an aggregation of techniques, values, judgments and relationships, thus acquires a complexity belied by the traditional singleminded, state-centered, democratic-value-enhancing "model" of surveillance as mere technique, that is, as "mere means." Surveillance has leaped the borders of the private and soft law (culture, mores, morals) within which it had been confined. The techniques now serve not as a proxy for or enhancement of governance, but as governance itself. Within the public sphere, that is the sphere of political governance, the consequences are significant, especially for law. In a surveillance governance culture, the relationship between law and surveillance is inverted. While traditional political communities assumed surveillance as a means to the enforcement of law, in the emerging surveillance culture law is the means through which surveillance is enforced. Law no longer serves its traditional function either as an organic repository of the regulation of a political community or as the positive expression of the will of the political community as legitimately enacted through its representatives in government. ${ }^{153}$

But law is also separated from surveillance in the emerging culture. Surveillance is fractured and partial, engaged in by every organ of public life and implemented through individual action, whether or not people are acting in an individual or representative capacity. States have privatized information gathering, ${ }^{154}$ international organizations seek to base a new international legal order on surveillance and self-monitoring, ${ }^{155}$ and private entities seek to utilize monitoring and self-monitoring regimes as a basis for economic and social regulation of relations between themselves and their various factors of production. ${ }^{156}$ Separated from the institutions of political communities in its social aspects, surveillance has become naturalized within the social culture. It is becoming the means through which law is expressed. And from this, surveillance has produced a fracturing of power, even as it has changed the nature of law. Foucault's prediction that power and law would be expressed in different ways in a world that has been able to move beyond symbolic utterance to surveillance, that is, would be expressed through technique, is coming to pass. ${ }^{157}$

153. For a discussion of the relationship between these two conceptualizations of law within traditional law based political communities, see Backer, supra note 31.

154. Sarbanes-Oxley Act of 2002, supra note 8.

155. See Backer, Multinational Corporations, supra note 29.

156. See Larry Catá Backer, Economic Globalization and the Rise of Efficient Systems of Global Private Law Making: Wal-Mart as Global Legislator, 39 ConN. L. Rev. 1739 (2007).

157. Foucault, supra note 32, at 145. 
Thus, surveillance serves as an expression of the apparatus of the constitution of the community observed. It helps solidify a "closed system, internally complete; yet ... also [one that] communicates, as a system, with the public national and supranational legal systems through which it may sometimes find expression, and that may serve as sources of norms." 158 But the unbundling of surveillance as these clusters of actions and judgments among multiple overlapping and sometimes conflicting closed systems (political, social, economic, national, and transnational communities) provides evidence of the emergence not only of techniques of governance, but of the complicity of self-governance and the proliferation of forms of governance beyond both the state and political frameworks previously privileged. ${ }^{159}$

For example, multinational corporations serve as the locus of a non-state regulatory power. In my earlier work, ${ }^{160}$ for example, I sought to sketch out the way in which fractured and networked non-state power is coalescing into functionally differentiated, porous yet autonomous units of governance beyond the nation-state. ${ }^{161}$ "There are four principle [sic] actors: (i) corporations and other enterprises; (ii) elements of civil society, primarily the great global economic and human rights nongovernmental organizations (NGOs); (iii) media; and (iv) consumers of the products of the corporations, civil society actors and the media, including consumers, customers, the investment community and financial markets. These actors have fundamentally adverse interests, are each dependent on the other, and derive authority from their respective interactions. ${ }^{\prime 162}$ This regulatory system is grounded, in large

158. Backer, supra note 156, at 1748. See also id. at $\mathbf{1 7 4 9}$ ("It is a lawmaking bounded by functional differentiation, that is, by lawmaking limited to a particular and specifically bounded/defined field of conduct related to the purposes for which the lawmaking community functions-applying to overlapping groups of people within multiple political, social, and ethnic communities.").

159. See Teubner, supra note 23, at 13-15; see also Andreas Fischer-Lescano \& Gunther Teubner, Regime-Collisions: The Vain Search for Legal Unity in the Fragmentation of Global Law, 25 Miсн. J. INT'L L. 999 (2004).

160. Backer, supra note 156 , at 1739.

161. This closed system is based on contract rather than legislation (perhaps now better understood as a form of contract with political and social dimension) and is meant to substitute for, or supplement, or bridge lapses in regulation by local, state and supra-national organs. Like most political systems, it is a functionally differentiated system. But while political systems are functionally differentiated along traditional substantive political bounds and limited by the territorial principle of the nation-state, the boundaries of this system are inherent in the nature of the relations among the actors. In the specific system analyzed, that boundary was marked by the limits of the relationship between a multi-national corporation and its suppliers and supply chain. See id.

162. Id. at 1748-49. See also id. at 1751-52 ("Private law making and private enforcement are possible because the system is built on a closed set of relationships among actors that, in the aggregate, produce norms, sustain viable systems of monitoring and communication among functionally distinct actors, and facilitate enforcement with reference to the rules generated by the system itself."). 
part, on surveillance among the actors in the closed system. ${ }^{163}$ The surveillance is internal to the multinational corporation and its principal constituencies (investors and consumers), ${ }^{164}$ and also exists as overlapping circuits of observation between the principal participants in this regulatory matrix-multinational and supplier ${ }^{165}$ supplier and non-governmental organization, ${ }^{166}$ non-governmental organization and the media, ${ }^{167}$ and each of these actors and the state and international political organizations. ${ }^{168}$ Governance surveillance thus constitutes both a reproduction of individual governance ${ }^{169}$ and a technique of power. Governance surveillance is thus now

163. The basic system characteristics include: "(i) an essential role of private law through contract; (ii) transparency, disclosure and its use by elements of civil society; (iii) a connection between civil society and media; (iv) a connection between media and public, consumers, public law enforcement institutions; and (v) a connection between public and internal corporate investigation and sanction apparatus." Id. at 1752.

164. Because of the importance of these actors, and the reactive nature of their role in the system, the control of customer/investor/markets information is critical. This comes as no surprisemodern securities markets are based on the importance of markets for information. Information management becomes as important as development, implementation and enforcement of behavior norms through contract.

Id. at 1760 .

165. The basic structure of coercive surveillance-self monitoring, reporting, and monitoring from outside with respect to those matters identified by the multinational corporation, are contained in the contract between the multinational and the supplier. The contract, in this respect, constitutes the institutional relationship between the entities on a basis far more extensive than merely economic. It contains social and political dimensions as well, the functioning of which is a function of surveillance and response systems. In the case of Wal-Mart, those norms are embodied in the contract and the "Standards for Suppliers." See id. at 1754-56.

166. "The most visible role of civil society is to monitor compliance with both public law and the contractual obligations of multinational with its stakeholders. In the context of supplier agreements, this requires monitoring the factories with contractual relations with Wal-Mart. Monitoring is difficult and expensive." Id. at 1758. This monitoring is accomplished both by interviewing the actors and otherwise obtaining information that must be disclosed to public shareholders and other constituencies.

167. The media serves as a critical factor in the effectiveness of private monitoring. And it serves as the most efficient means of communication among all of the actors within the private regulatory system. It is also a player in its own right, achieving substantive results through its power to choose among items of information for publication.

Id. at 1749 .

168. These political entities produce their own forms of regulatory surveillance, discussed above, applicable especially against a pubic corporation whose securities are registered in the United States, like Wal-Mart. See id. at 1741.

169. Aristotle, The Politics of Aristotle (Peter L. Phillips Simpson trans., University of North Carolina Press, 1997). Recall that Aristotle laid the modern foundation for a theory of state based on reproduction of governance from the lowest and least significant grouping in society (the family) through the grandest empire. See id. This methodology of embedded replication of cultur- 
structured within both public (law) and private (contract) relationships. The objects of these systems are both states and non-state actors, each of which may be compelled or encouraged by a variety of actors and stakeholders.

As a consequence, surveillance has become ubiquitous, a mirror on self and social organization, a reflection of the techniques and self-constitution of power, and an expression of normative values which bound those communities thus constituted. Again, the autonomous supplier chain contract based system of large multinationals provides a window onto the character of this consequence.

Wal-Mart gets the best of both worlds--it purchases low cost supplies until the cost of the supplies includes a dip in economic goodwill, at which point Wal-Mart sanctions its supplier. This repairs the damage to Wal-Mart's economic goodwill after it has received the benefit of low-cost supplies. It has externalized, to some extent, the costs of monitoring, by relying on the efforts of civil society. But civil society is better off as well. Wal-Mart is good for the business of civil society as long as Wal-Mart cannot perfectly manage its suppliers in accordance with its own standards. The media is better off as well. The dynamic relationship between supplier, multi-national and civil society generates information that can be packaged as "news." Production of this sort of news is profitable for media entities and reinforces the media's role as information gatekeeper and authoritative source of "facts." Non-traditional media (internet and other sources) also profit. Their ability to transmit information about multinationals from elements of civil society reinforces their own legitimacy and strengthens network ties between them and civil society organizations. The suppliers are better off as well, gambling that the imperfect process of inspection and audit will protect them. But ironically, even the workers are better off. The standards themselves, and the fear of enforcement, change the base-line for the treatment of workers across the board. ${ }^{170}$

ally distinct patterns of governance is not confined to the West. Confucian notions of family, state, hierarchy, obedience and harmony also conflate (or assume a necessary replicating articulation) of a primal form across governance divisions whether formally constituted (the state) or informally constituted. See Berthrong, supra note 66, at 129-30.

170. Backer, supra note 156 , at $1781-82$. 
Surveillance has morphed from an incident of governance to the basis of governance itself. It is both government (apparatus) and governmentality (its selfconception and complicity, the prisoner becomes his own keeper). In this sense, surveillance has become the new regulatory mechanism. And law is becoming its servant. And the state, either as the traditionally conceived apex of political order, or as the repository of large aggregations of power within an international state system, now serves as a (but not the) nexus point for the regulatory power of technique. It is in this sense that we can speak of the "death" of the "state" or the "rise" of a transnational political system, or the "death" of the public/private divide or even the construction of non-public autopoietic systems. ${ }^{171}$

I have suggested illustrations of these propositions. The examples I have drawn on suggest that surveillance governance has begun to form patterns of expression that merit additional study. Among the emerging patterns are municipal and formal surveillance. These systems appear to be distinguished by their formal public law based characteristics. They are grounded in law, and their formal aspects appear to have an upstream vector (surveillance proceeds from lower to higher authorities for the benefit of the higher formal, and legally constituted, authority) and are, as a function of their basis in law, coerced. Examples of this form of surveillance system might include systems of corporate regulation. ${ }^{172}$ They acquire a global and transborder dimension in emerging global systems of voluntary corporate best practices and "social responsibility."173

Another emerging pattern of surveillance governance is transnational and informal surveillance. These systems appear to be distinguished by their informal, that is, functional, based characteristics. They are grounded in contract rather than in law and may have both an upstream and horizontal set of control vectors. They are sometimes coerced (in the context of contract obligations) but maintained through systems of surveillance incentives. Examples of such private transnational systems include supplier chain surveillance systems, like those founded on the social

171. See, e.g., François Ewald, The Law of Law, in Autopoletic Law: A New Approach to Law AND Society 36, 39-41 (Gunther Teubner ed., 1987) (examining its relationship to traditional theories of public law, especially the theories of Hans Kelson); Niklas Luhmann, Law as a Social System, 83 Nw. U. L. Rev. 136 (1989).

172. While the focus of this article has been on American corporate governance, and specifically with the example of SOX, supra note 8, the pattern also appears in other corporate governance systems, principally those emerging in Europe. See Backer, supra note 50.

173. See supra note 65 and accompanying text for an example of the work of the OECD in this respect. 
and economic relations between multinational corporations and their suppliers. ${ }^{174}$ But in its more horizontal dimension include the rising systems of product certification programs ${ }^{175}$ or private systems of performance evaluation, for example public and private global security firms and bond-rating agencies. ${ }^{176}$

A third emerging pattern of surveillance governance includes transnational and formal surveillance systems. These systems appear to be distinguished by their hybrid characteristics. They tend to involve public-private or public multilevel partnerships, grounded in both law and in contract, with downstream vectors (information proceeds from the greater legally constituted entity to the less formally constituted or public entity, for the benefit of both the disciplining of the greater entity but the benefit of the less formally constituted entity). Surveillance may be both law and contract based. These surveillance systems tend to focus on states as the objects of surveillance and public-private entities as the monitor. Examples might include the World Bank, especially in its anti-corruption and technical assistance programs. ${ }^{177}$ It might also include the International Monetary Fund, especially its country surveillance programs and the surveillance elements of its conditional lending programs. ${ }^{178}$ These systems all share something in common-the effectuation of broadly-based behavior aspirational goals with very specific and concrete application through regimes of monitoring, disclosure, observation, intervention, and open-textured stakeholder intervention. Information is used by the principals to the governance relationship but is dependent on the participation of multiple actors in monitoring, reporting and reshaping. Thus, the IMF's lending programs require the active participation of governments, business, civil society, and the media to create an open-textured, constant state of vigilance grounded in the norms that constitute the conditions to the loan.

174. See supra notes 160-70 and accompanying text (looking at the example of the system set up by Wal-Mart).

175. See, e.g., Errol Meidinger, The Administrative Law of Global Private-Public Regulation: The Case of Forestry, 17 Eur. J. InT'L Law 47 (2006). See also supra note 130 and accompanying text.

176. See generally Katharyne Mitchell \& Katherine Beckett, Securing the Global City: Crime, Consulting, Risk, and Ratings in the Production of Urban Space, 15 Ind. J. Global Legal Stud. 75 (2008).

177. See supra notes 82,134 and accompanying text.

178. See supra note 134 and accompanying text. 


\section{Conclusion}

"The policing of a postmodern world emerges as a complex set of visual and semiotic practices, an expanding spiral of mediated control." ${ }^{179}$ Surveillance, what we are coming to understand as that complex of techniques and assumptions, is assuming a central place within this policing. And indeed, as this article suggests, policing is quickly replacing law (either organic or positive law) as the framework through which collectives (the state, the corporation, and religion, to name the most well-known actors) govern. This article has sought to unpack the complex characteristics of surveillance and to suggest the ways in which it has acquired normative significance. Surveillance is both shaped by the normative assumptions of the community from which determinations to harvest information springs and also shapes those assumptions in the act of harvesting. A society that chooses among items of information to be harvested reifies and privileges those forms of data and invests each with meaning that lead implicitly to judgment in which privileged information counts for more than the rest.

Even the concept of information is subject to interrogation. Much that passes for fact is judgment, which the act of harvesting is meant to reinforce. The descriptor "fact" or "data" is sometimes a veil used to hide judgments and objects hidden within assumptions and presumptions that together constitute the "thing" identified as "fact" or "data. ${ }^{180}$ Concepts like "race," "ethnicity," and "religion" are perhaps more legitimately contestable "conclusions" or "suppositions" than they are concrete "facts" or "data." Yet a determination to "gather" information about each can follow only from a conclusion that such a thing exists and is bound by a certain set of characteristics. Likewise, the act of harvesting itself suggests the characteristics of the things harvested and confirms power relationships among those to be harvested, the harvester, and the holder of the data harvested. Information itself serves social, cultural, and institutional functions. Conversations about surveillance serve indirectly to suggest societal decision making on the meaning of language, the objectification of intangible conditions (and status), the characteristics of group membership, and the assignment of ownership of data. This data can now simultaneously serve social, political, and economic roles in the hands of both private and public actors who serve as informatics stakeholders.

179. Jeff Ferrell \& Neil Websdale, Materials for Making Trouble, in MAKIng Trouble supra note 116, at 3,15 .

180. For a general discussion of veiling in its political and legal context, see Larry Catá Backer, Forward: Constituting Nations-Veils, Disguises, Masquerades, 20 PenN St. Int'L L. Rev. 329 (2002). 
It follows that information and control function together as technique and as its framework. The control elements focus on the systems aspects of surveillance. Systems, in this case, are understood to encompass both the ministerial constructs through which surveillance techniques are structured and given effect, and the institutions that operate such systems. Information is power. That is well understood. But information farming is more power still. The control of those farming operations provides a source of power. It also provides a technique for controlling challenges to such power. The great contribution of twentieth century totalitarian systems to American democracy, perversely enough, has been its understanding of the utility of information as a means to power and its retention. The surveillance cultures of postrevolutionary $\mathrm{Cuba}^{181}$ appear again in the interstices of the Sarbanes-Oxley Act.

Control implicates governance. Surveillance suggests a new basis of governance-one that is not grounded on the old constructs of positive law imposed through expressions of the will of the community or its sovereign institutions. Instead, governance assumes a more complex form, one in which the traditional boundaries of community become much more fluid and porous, even as communities become more rigidly defined and differentiated. Yet, the caution sounded is worth remembering as this inquiry has ended. That caution ought to remind those who deepen and broaden surveillance regimes as the modern vehicle for regulation that this form of control may have significant effects on the nature and functioning of the American republic and on the nature of the relationships of individuals to each other and to the institutions that may assert some coercive power over their choices, outlooks, and positions. "By requiring citizens to live in glass houses without curtains, totalitarian societies deny their status as individuals and 'this transformation of a man from subject to object is experienced as shame." 182 Surveillance regimes, as law beyond the state, are here to stay. Their complexities, manipulability, and regulatory effects should not be underestimated.

181. See Backer, supra note 127 , at 921 n.7:

It is with some irony that one can access on the official website of the Marxist-Socialist government of Cuba the suggestion that the American government has attempted to create its own version of the revolutionary neighborhood committees for the defense of the revolution-Comités de Defensa de la Revolución. These committees were established by the Cuban government after 1959 to enlist citizens in the monitoring and reporting of their fellow citizens in the cause of the Cuban revolution, that is, against acts of counter revolutionary terrorism.

182. Rosen, supra note 5, at 112 (quoting in part, Milan Kundera, Testaments Betrayed 261 (1995)). 